https://doi.org/10.15407/ujpe65.8.709

O.V. TOMCHUK ${ }^{1,2}$

1 Taras Shevchenko National University of Kyiv

(4, Academician Glushkov Ave., Kyiv 03022, Ukraine; e-mail: tomchuk@jinr.ru)

2 Joint Institute for Nuclear Research

(6, Joliot-Curie Str., Dubna 141980, Russia)

\title{
THE CONCEPT OF FRACTALS
}

IN THE STRUCTURAL ANALYSIS OF NANOSYSTEMS: A RETROSPECTIVE LOOK AND PROSPECTS

\begin{abstract}
The concept of fractals is widely used in various fields of science. By an example of the results obtained by L.A. Bulavin's scientific school, the tendency toward a more intense application of the fractal analysis to structural studies of nanosystems has been demonstrated. It is shown that the peculiarities in the distribution of nanosystems over their fractal dimensions are related to the mechanisms of growth and aggregation of the dispersed phase. An important aspect of the considered issue is the kinetics of the process under the influence of various factors. The leading role of small-angle scattering methods (analysis in the reciprocal Fourier space) together with microscopy ones (analysis in the direct space) used to study advanced nanostructured materials in various states of matter is emphasized.
\end{abstract}

Keywords: fractals, fractal dimension, nanosystems, aggregation.

\section{Introduction}

Forty-five years have passed since B. Mandelbrot introduced the term fractal [1]. Since then, the fractal concept has deeply penetrated into various areas of our life, such as mathematics and physics, chemistry, biology, geology, economics, painting, and design [2]. This approach enables a quantitative description of the systems characterized by scale invariance to be performed. This type of symmetry is naturally associated with the power distributions of elements of the system. The exponents of such distributions include its dimension. In the case of fractals, the latter differs from the dimension of the space that contains the system and even can take fractional values. Examples of such objects have been known to mathematicians for a long time. In particular, these are the Weierstrass function and the von Koch and Peano curves [2]. However, the development of uni-

(C) O.V. TOMCHUK, 2020

ISSN 2071-0194. Ukr. J. Phys. 2020. Vol. 65, No. 8 fied approaches to describe both abstract and real natural objects belongs exactly to B. Mandelbrot.

The concept of fractal was especially successful in the physics of nanosystems, where its application has made clearer the understanding of the structural features in disordered, at first glance, systems. Fractal relationships found their reflection in a number of in situ methods, which allowed a precise determination of the substance structure parameters on the nanoscale to be performed. The scattering of radiation of various types (neutrons, X-rays, light), various kinds of microscopy (scanning and transmission electron, atomic force, and optical polarization ones), adsorption and rheological techniques, and so forth should be classified to this group of methods. They are actively applied to a diversity of nanoobjects that are included into the substance in various aggregate states, which is evidenced by a steady growth in the number of scientific publications devoted to the fractal analysis of structural data. 


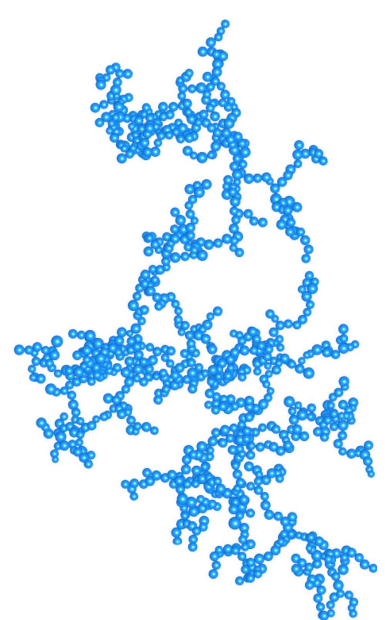

Fig. 1. Example of a volume fractal: a model cluster of colloidal particles with a fractal dimension of 1.5

It seems impossible to trace this trend in detail on the basis of the whole body of available literature sources, especially in the framework of a single review article. However, focusing the attention on a certain set of works that have a common basis, it is still possible to reveal certain regularities in the application and combination of different methods, the statistical distribution of fractal dimensions, and the chronology of the interest growth to this topic. For instance, publications of scientists belonging to the same scientific school can be sampled for the analysis. A remarkable example of such a school is the community of disciples of Academician of the National Academy of Sciences of Ukraine, Professor Leonid Bulavin. The scientists who started their careers at the Department of Molecular Physics of the Faculty of Physics at the Taras Shevchenko National University of Kyiv are now working at many institutions in Ukraine and abroad. It is their publications that were taken as a basis for this review. Thus, the aim of this work was to analyze the works of the scientific school of Prof. L.A. Bulavin in which the concept of fractal was applied to the structural diagnostics of nanosystems, as well as to establish the regularities in the distribution of researched objects over the types of fractal structures.

\section{Fractal Nanosystems and Methods of Their Research}

Natural fractals are objects (systems) that are identically ordered in a certain scale range. Therefore, in a statistical sense, any fractal system is self-similar [2] (Fig. 1). A mathematical quantity that makes a description of disordered systems possible is the parameter of fractal dimension. It can acquire any value within an interval from 0 to 3 . For connected sets, such as nanoparticle clusters, this is an interval from 1 to 3 . Very prolate or very oblate objects can also be formally classified to fractals because their dimensions ( 1 and 2, respectively) also differ from the dimension of the Euclidean space, where they are located.

In the general case, the volume fractal dimension $D_{V}$ is introduced using the mass-to-radius ratio: the number of structural units $N$ confined in a sphere of the radius $r$ is determined as

$N \propto r^{D_{V}}$

Against the background of the global problem of physical chemistry concerning the determination of the specific surface area of colloidal formations, we note that the fractal clusters are characterized by the following relation between the area and the volume:

$S \propto V^{D_{V} / 3}$

which means a larger specific surface area for systems with a higher fractal dimension. From whence, one can see that the surface occupies a substantial volume in considerably branched fractals $\left(D_{V} \rightarrow 3\right)$.

In the literature, there are many kinetic models of aggregation processes giving rise to the formation of stochastic fractal structures. The fractal construction algorithms can be divided into two types: the particle-cluster and cluster-cluster aggregations. Some aggregation algorithms developed on the basis of stochastic processes are introduced in accordance with their natural analogs (e.g., the diffusion-limited aggregation, the reaction-limited aggregation, and so on) [2]. In addition, there are a number of models for the fractal growth of clusters. Some of them came from the physics of polymers (the statistical coil model, the Florey model), the others from the physics of phase transitions and critical phenomena (the percolation cluster). Thus, the formalism of fractal dimension allows peculiar classes of universality to be introduced in accordance with the models of fractal aggregation. As was marked above, the fractal dimension characterizes the degree of disorder of the system. From this point of view, the pair

ISSN 2071-0194. Ukr. J. Phys. 2020. Vol. 65, No. 8 
correlation function has a monotonically decreasing asymptotics at $r \rightarrow \infty$,

$g(r) \propto r^{D_{V}-3}$.

The physical processes that are used to measure a certain system are often convenient to be considered in a reciprocal space. The intensity of small-angle scattering is known to be proportional to the Fourier transform of the correlation function [3, 4]. From whence, it follows that the scattering intensity (the differential scattering cross-section per unit volume) for bulk fractal systems with the dimension $D_{V}$ looks like

$I(q) \propto q^{-D_{V}}$.

In the works devoted to the analysis of fractal structures, only the asymptotic expression (4) is used, as a rule, to estimate the fractal dimension, although a more detailed analysis is available in the framework of the form-factor method.

Besides volume (mass) fractals, nanosystems can also contain surface fractals (Fig. 2). The latter can be defined as interfaces that are also characterized by self-similarity. Their dimension $D_{S}$ differs from a value of 2 (this value is a characteristic of Euclidean surfaces) and varies within an interval from 2 to 3 . Thus, we have a certain branched interface on a uniform substrate. In this case, the pair correlation function has the following asymptotics at $r \rightarrow 0$ :

$g(r) \propto 1-C r^{3-D_{S}}$.

For surface fractals, the intensity of small-angle scattering looks like

$I(q) \propto q^{D_{S}-6}$.

From whence, it follows that, for a fractal interface, the variation interval for the power exponent differs from that inherent to mass fractals, so that the method can distinguish between objects of two types. A limiting case for a fractal surface is a smooth Euclidean surface, for which $D_{S}=2$. In this limit, the isotropic scattering by a two-phase system with a smooth interface is called the Porod scattering.

Another interval of the power exponent (from 4 to 6 ) characterizing the scattering intensity recession corresponds to the so-called diffusive surface around

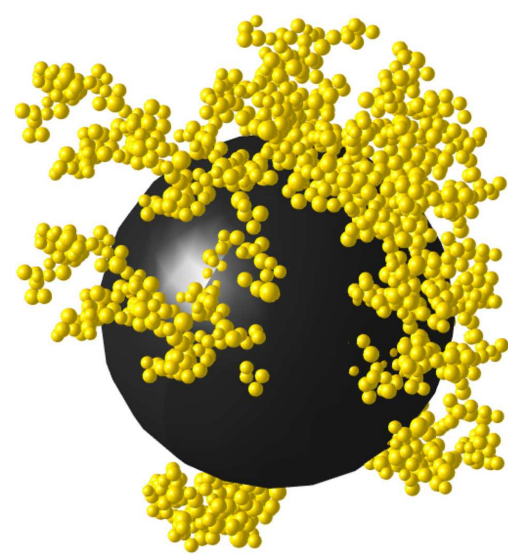

Fig. 2. Example of a surface fractal: a specific aggregation of nanoparticles on the surface of a submicron particle. The surface fractal dimension equals 2.5

a homogeneous core [5]. Here, we deal with a weak inhomogeneity, but without scale-invariant properties.

Hence, the method of small-angle scattering allows the structures of various types to be identified by analyzing the behavior of the power exponent in their dependences of the scattering intensity decay as a function of the transferred wave vector magnitude $q$. In other words, an experimenter can immediately determine whether the examined objects are prolate or oblate, whether they are scale-invariant or not, whether the surfaces of nanoparticle possess diffusive or fractal properties, or whether they are smooth.

While analyzing the structure of both the surface and volume fractals in the direct space, it is important to determine the so-called cell dimension. The corresponding method is based on replacing the complicated shape of an object with a grid of $d$-dimensional cubes, each with the side $\varepsilon$. Let $N(\varepsilon)$ be the number of cubes containing at least one point of the object. Then, for the volume $V$, we may approximately write

$V \approx N(\varepsilon) \varepsilon^{d}$

Hence, the number of test bodies required to cover the given set of points depends on the cube side length according to the relation

$N(\varepsilon) \propto \varepsilon^{-D}$.

The quantity $N(\varepsilon)$ can be interpreted as the number of pixels required to represent a system with the resolution $\varepsilon$. 


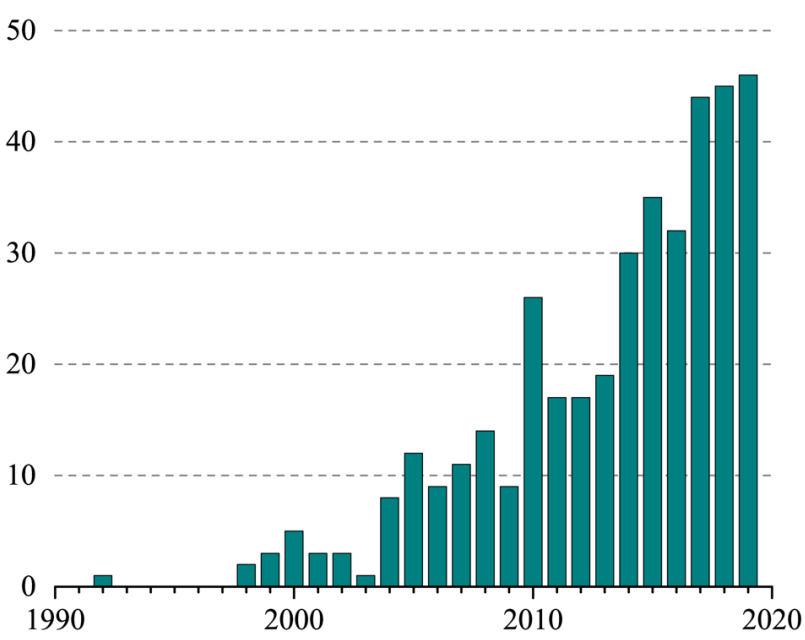

Fig. 3. Growth of the number of publications of L.A. Bulavin's scientific school on fractal topics during the last thirty years [3$394]$

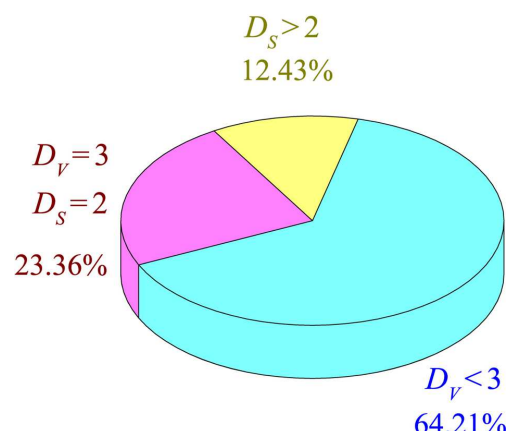

Fig. 4. Comparison of researched systems with respect to their fractal dimensions: volume and surface fractals, as well as non-fractal systems

Surfaces that can be described by a single-valued function $z(x, y)$ are studied with the help of the crosssection method. When the cross-sections of such a surface are oriented perpendicularly to the $z$-axis, the obtained level lines compose a set of closed curves. Those curves have a topological dimension equal to 1 , so that they are easier to study than the surface itself. The fractal dimension $D^{\prime}$ of the level lines is connected with the surface dimension $D_{S}$ by the formula

$D^{\prime}=D_{S}-1$.

Because of the symmetry of the $x$ - and $y$-axes, the obtained set is self-similar. To determine the fractal dimension, the perimeter versus area relation, which is similar to relation (2), can be used:

$P \propto S^{D_{S} / 2}$

where $P$ is the length of the cross-section boundary, and $S$ the cross-section area. If the experimental determination of the area becomes a difficult task, the contours are analyzed using the cell dimension method applied to the two-dimensional case [Eqs. (7) and (8)]. This approach is widely used while analyzing the data obtained for the surface of nanoobjects, e.g., using atomic force microscopy.

In every particular case, specific experiments may be required in order to indirectly determine the fractal dimension - alternatively, with the help of Eq. (1). For example, the fractal morphology of aerosol particles can be described on the basis of the results of the sedimentation analysis or by estimating their behavior in the electrical or gravitational field. The results of applications of those methods are discussed in the next section in the framework of the fractal approach.

\section{Experimental Studies of Nanosystems with Fractal Properties}

During the last thirty years, the representatives of L.A. Bulavin's scientific school have studied, along with other objects, various nanosystems [3394], including polymers, composites, and liquid systems. The plot in Fig. 3 testifies that the number of works devoted to this topic has been constantly growing since the 1990s. The analyzed sample of works includes the papers, where the studied systems either revealed fractal properties or, on the contrary, presented evidence of their dense packing or homogeneity $\left(D_{V}=3\right)$. In general, this behavior corresponds to the global trend in the science of nanostructured materials. The fractal description is applied more and more frequently because it can reveal new structural details that are often associated with macroscopic physico-chemical properties of the substance.

An analysis of the quantitative distribution of nanosystems over their dimensions demonstrates that less than a quarter of the researched specimens did not reveal fractal properties and, in general, could be described as Euclidean geometric bodies (Fig. 4). It was taken into account that several different systems could be studied in the same article. More than $64 \%$ of nanosystems were identified as volume frac- 
tals with that or another dimension. About $12.4 \%$ of the studied specimens contained nanoformations with a fractal surface, i.e. the dimension of surface inhomogeneities exceeded a value of 2 . This unexpected result testifies that a uniform mass distribution or an aggregation with dense packing at the nanolevel is rather an exception than a rule for practically important nanosystems. Physico-chemical conditions occurring at the natural or industrial synthesis often favor the emergence of a substantial inhomogeneity and the branch character of the system. It is the scale-invariant symmetry within a certain interval of sizes not exceeding a few micrometers that helps one to reveal an obscured order in such objects.

Furthermore, the distribution of nanosystems over their fractal dimensions turned out very non-uniform (Fig. 5). The majority of objects had a dimension of 2. This circumstance is a result of several important contributions. First, such objects as thin films [262, 263, 349, 359, 369], lipid bilayers [155, 191, 255], nano-sized laponite disks $[162,193]$ and some others are quasi-two-dimensional ones. Second, these are polymer systems in the statistical coil state under $\theta$-conditions [315]. Third, these are branched fractal aggregates of nanoparticles, the formation of which is governed by mechanisms that are close to the model of ballistic cluster aggregation or reaction-limited aggregation [71, 171, 288].

The second place, according to the statistics, is occupied by objects with a fractal dimension of 1 . These are substantially anisotropic prolate bodies. Their rod-like shape can be close to those of ellipsoids of rotation, cylinders, or prisms, but the main thing is that their size along one of the axes is much larger than the sizes in the other two directions. Such systems include amyloid solutions of proteins [367], nanoparticle chains [285, 286], nanotubes [394], and others.

Two more peaks are also observed in Fig. 5 in the vicinities of fractal dimensions of 2.4 and 1.7. Those values can be associated with the mechanisms of diffusion-limited single-particle and cluster-cluster aggregations, respectively. Thus, the aggregation kinetics is governed by such external factors as the temperature, pressure, and electromagnetic field, as well as the physico-chemical parameters of the nanoparticle surface. At the same time, changes of the kinetics type - e.g., the diffusion-limited or the reactionlimited mode - lead to differences in the structuring from the viewpoint of fractal parameters. The value

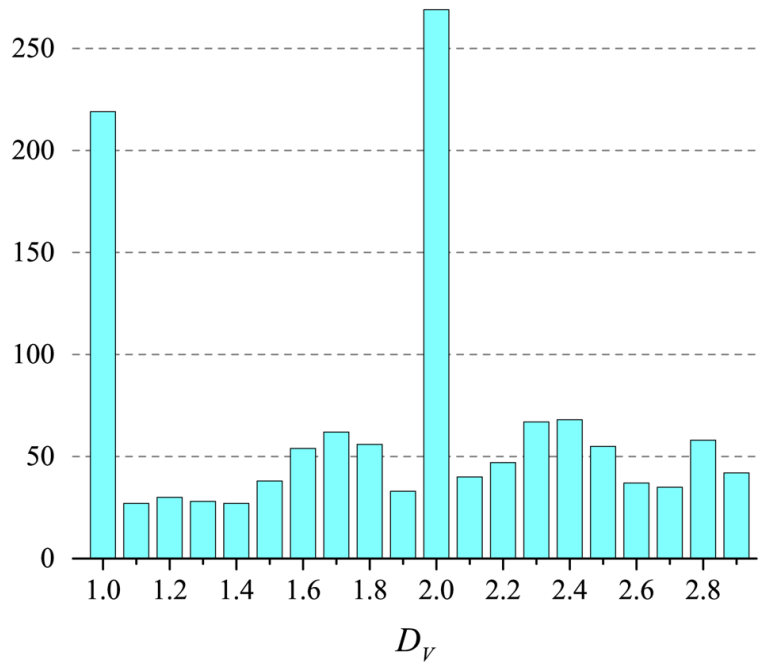

Fig. 5. Distribution of nanosystems with volume fractals over the dimensions of the latter

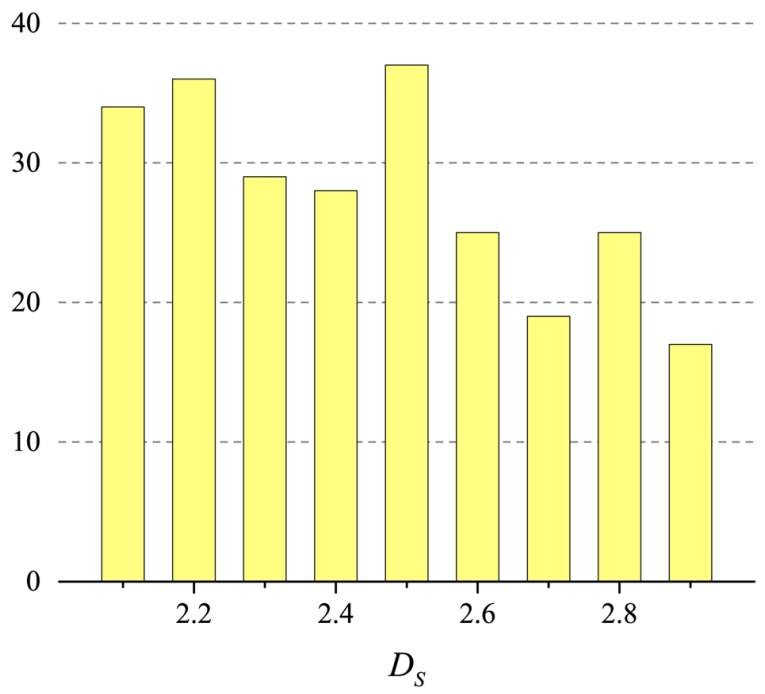

Fig. 6. Distribution of nanosystems with surface fractals over the dimensions of the latter

$D_{V} \approx 2.4$ is typical of the clusters of detonation nanodiamonds in polar solvents [5,130,147, 196, 230,351], aqueous suspensions of fullerene aggregates [311,362], polymer-surfactant mixtures [315], and others. The value $D_{V} \approx 1.7$ can be observed for aggregates in some magnetic colloids [91,308,367], proteins in mesoporous silicates [326], aluminum oxyhydroxide aerogel [236], and others.

On the contrary, the distribution of nanosystems over the surface fractal dimension (Fig. 6) is rather uniform, with a small decrease far from a smooth 


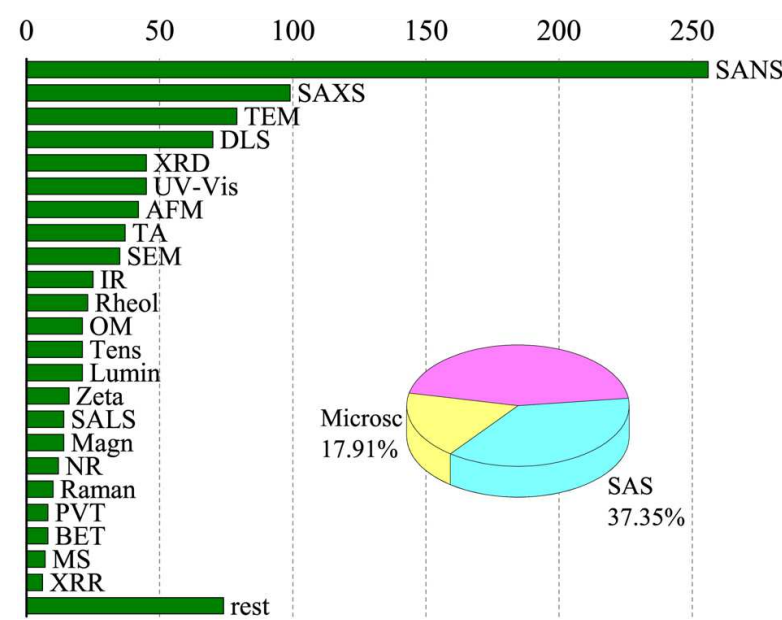

Fig. 7. The frequency of applications of the methods used in the researches of nanosystems. Notations: SANS - smallangle neutron scattering; SAXS - small-angle X-ray scattering; TEM - transmission electron microscopy; DLS - dynamic light scattering; XRD - X-ray diffraction; UV-Vis - light absorption spectroscopy in the ultraviolet and visible spectral intervals; AFM - atomic force microscopy; TA - thermal analysis, including differential scanning calorimetry and thermogravimetric analysis; SEM - scanning electron microscopy; IR - infrared spectroscopy; Rheol - rheological studies; OM - optical microscopy; Tens - tensiometry; Lumin - luminescent analysis; Zeta - electrokinetic potential measurements; SALS - smallangle light scattering; Magn - magnetometry; NR - neutron reflectometry; Raman - Raman scattering; PVT - determination of the thermal equation of state; BET - determination of the specific surface by low-temperature adsorption (the BrunauerEmmett-Teller method); MS - mass spectrometry; XRR - Xray reflectometry; rest - other methods inserting a small contribution to the given statistics. The insert demonstrates the cumulative fractions of small-angle radiation scattering methods, including neutrons, X-rays, and visible light (SAS), as well as microscopy methods, including electron, atomic force, and optical microscopies (Microsc)

surface at $D_{S}=2$. At first glance, this is a result of minimizing the corresponding thermodynamic potential by reducing the free surface. Nevertheless, this issue has to be studied more thoroughly, because the examined processes are actually strongly nonequilibrium. The only exception is the value $D_{S}=2.5$, which points to an analogy with the bulk variant of the diffusion-limited single-particle aggregation.

Various modern structural methods were used to study the properties of nanosystems. In Fig. 7, a statistical distribution of the application frequency of structural diagnostic methods in the works covered in this review is depicted. It was taken into account that several methods could be used simultaneously in the same work. According to the diagram, the methods of small-angle scattering of neutrons, X-ray radiation (including synchrotron radiation), and visible light are the most suitable for studying the fractal characteristics: together, they comprise more than $37 \%$. It is also worth noting the share of microscopy methods. In particular, the optical, electron, and atomic force microscopy methods were used in almost $18 \%$ of the studies of fractal nanosystems in the direct space.

\section{Conclusions}

Hence, the concept of fractals has found its wide application in structural studies of nanosystems. By an example of the results obtained by L.A. Bulavin's scientific school, the tendency to a significant growth of applications of the fractal analysis of matter in various physical states was demonstrated. It was shown that a substantial number of nanosized formations reveal scale-invariant structural properties in the bulk or at the surface. The distribution of nanosystems over their dimensions is considerably non-uniform, which testifies to the predominance of certain growth mechanisms on the nanoscale. The important role of the microscopy and small-angle scattering methods in the framework of complex structural studies of nanosystems with fractal properties is emphasized. The presented results can be extrapolated, to a large extent, to the current state of nanophysics in whole.

Despite the significant progress in the examined issue, the mathematical concept of fractals still remains at the stage of its genesis. Its further development will be associated, first of all, with precision experiments aimed at determining the structure of not only selfsimilar but also self-affine systems, and at evaluating their anisotropy and lacunarity. An active application of this tool can help to deepen our understanding of the nanoworld.

The author is grateful to L.A.Bulavin, O.A.Kyzyma, A.V.Nagornyi, O.M. Alekseev, O.S.Svechnikova, T.Yu. Nikolaienko, and I.S. Voiteshenko (Taras Shevchenko National University of Kyiv), O.I. Ivankov and D.V.Soloviov (Institute for Safety Problems of Nuclear Power Plants of NASU), V.V. Klepko (Institute of Macromolecular Chemistry of NASU), M.V.Avdeev (Joint Institute for Nuclear Research), V.I. Petrenko (Basque Center for Materials, Appli- 
cations and Nanostructures), V.M. Haramus (Helmholtz-Zentrum Geesthacht), V. Pipich, A.V.Feoktystov, and T.O.Kyrey (Heinz Maier-Leibnitz Zentrum), V.F. Korolovych (Harvard University), and M.O. Golub (University of Tartu) for productive discussions on both the research objects and methods.

1. B.B. Mandelbrot. On the geometry of homogeneous turbulence, with stress on the fractal dimension of the isosurfaces of scalars. J. Fluid Mech. 72, 401 (1975).

2. B.B. Mandelbrot. The Fractal Geometry of Nature (Freeman, 1982) [ISBN: 0-7167-1186-9].

3. V.I. Petrenko, A.V. Nagornyi, I.V. Gapon et al. Magnetic fluids: Structural aspects by scattering techniques. In: Modern Problems of Molecular Physics. Selected Reviews from the 7th International Conference "Physics of Liquid Matter: Modern Problems", Kyiv, Ukraine, May 2731, 2016, edited by L.A. Bulavin, A.V. Chalyi (Springer, 2018), p. 205.

4. O.V. Tomchuk, L.A. Bulavin, V.L. Aksenov et al. Smallangle scattering in structural research of nanodiamond dispersions. In: Modern Problems of the Physics of Liquid Systems. Selected Reviews from the 8th International Conference "Physics of Liquid Matter: Modern Problems", Kyiv, Ukraine, May 18-22, 2018, edited by L.A. Bulavin, Limei Xu (Springer, 2019), p. 201.

5. O.V. Tomchuk, L.A. Bulavin, V.L. Aksenov et al. Smallangle scattering from polydisperse particles with a diffusive surface. J. Appl. Cryst. 47, 642 (2014).

6. Y. Melnichenko, M. Agamalyan, V. Alexeev et al. Crossover between tricritical and critical demixing regimes of polymer solution: Small-angle neutron scattering data. Europhys. Lett. 19, 355 (1992).

7. V.M. Garamus, J.S. Pedersen. A small-angle neutron scattering study of the structure of graphitized carbon black aggregates in Triton X-100/water solutions. Colloids Surf. A 132, 203 (1998).

8. Yu. Prilutski, S. Durov, L. Bulavin et al. Study of structure of colloidal particles of fullerenes in water solution. Mol. Cryst. Liq. Cryst. 324, 65 (1998).

9. V. Garamus, K. Kameyama, R. Kakehashi et al. Neutron scattering and electrophoresis of dodecyldimethylamine oxide micelles. Colloid Polym. Sci. 277, 868 (1999).

10. V.M. Nadutov, L.A. Bulavin, V.M. Garamus. Analysis of small-angle neutron scattering from $\mathrm{Fe}-18 \mathrm{Cr}-$ $10 \mathrm{Mn}-16 \mathrm{Ni}-0.5 \mathrm{~N}$ and $\mathrm{Fe}-21 \mathrm{Cr}-10 \mathrm{Mn}-17 \mathrm{Ni}-0.5 \mathrm{C}$ austenite. Mater. Sci. Eng. A 264, 286 (1999).

11. Y.I. Prilutski, E.V. Buzaneva, L.A. Bulavin et al. Structure, dynamics and optical properties of fullerenes $\mathrm{C}_{60}$, $\mathrm{C}_{70}$. Carbon 37, 835 (1999).

12. H.M. von Minden, K. Brandenburg, U. Seydel et al. Thermotropic and lyotropic properties of long chain alkyl glycopyranosides. Part II. Disaccharide headgroups. Chem. Phys. Lipids 106, 157 (2000).
13. V.M. Garamus, J.S. Pedersen, H. Kawasaki et al. Scattering from polymerlike micelles of TDAO in salt/water solutions at semidilute concentrations. Langmuir 16, 6431 (2000).

14. J. Merta, V.M. Garamus, A.I. Kuklin et al. Determination of the structure of complexes formed by a cationic polymer and mixed anionic surfactants by small-angle neutron scattering. Langmuir 16, 10061 (2000).

15. L. Bulavin, I.I. Adamenko, V.M. Sysoev et al. The model calculation of the phase (p-T) diagram for fullerene $\mathrm{C}_{60}$. Fullerene Sci. Technol. 8, 615 (2000).

16. L. Bulavin, I. Adamenko, Y. Prylutskyy et al. Structure of fullerene $\mathrm{C}_{60}$ in aqueous solution. Phys. Chem. Chem. Phys. 2, 1627 (2000).

17. Y.I. Prilutski, S.S. Durov, L.A. Bulavin et al. Structure, vibrational, and calorical properties of fullerene $\mathrm{C}_{60}$ in toluene solution. Fullerene Sci. Technol. 9, 167 (2001).

18. Y.I. Prilutski, S.S. Durov, L.A. Bulavin et al. Structure and thermophysical properties of fullerene $\mathrm{C}_{60}$ aqueous solutions. Int. J. Thermophys. 22, 943 (2001).

19. L.A. Bulavin, I.I. Adamenko, V.M. Yashchuk et al. Self-organization $\mathrm{C}_{60}$ nanoparticles in toluene solution. J. Mol. Liq. 93, 187 (2001).

20. V.M. Nadutov, V.M. Garamus, A.K. Islamov. Small-angle neutron scattering and the Moessbauer effect in nitrogen austenite. Phys. Solid State 44, 686 (2002).

21. J. Merta, V.M. Garamus, R. Willumeit et al. Structure of complexes formed by PDADMAC and sodium palmitate. Langmuir 18, 7272 (2002).

22. V.V. Shilov, Y.P. Gomza, V.V. Klepko et al. Gel electrolyte system based on polyvinyl chloride with addition of $\mathrm{LiClO}_{4}$ /propylene carbonate: Structure, morphology, thermal and conductivity properties. IEEE Trans. Dielectr. Electr. Insul. 9, 551 (2002).

23. V.M. Garamus, J.S. Pedersen, H. Maeda et al. Scattering from short stiff cylindrical micelles formed by fully ionized TDAO in $\mathrm{NaCl} /$ water solutions. Langmuir 19, 3656 (2003).

24. C.A. Ericsson, O. Soderman, V.M. Garamus et al. Effects of temperature, salt, and deuterium oxide on the self-aggregation of alkylglycosides in dilute solution. 1. $n$ nonyl- $\beta$-d-glucoside. Langmuir 20, 1401 (2004).

25. M. Kadi, P. Hansson, M. Almgren et al. Mixed micelles of fluorocarbon and hydrocarbon surfactants. A small angle neutron scattering study. Langmuir 20, 3933 (2004).

26. M.V. Avdeev, A.A. Khokhryakov, T.V. Tropin et al. Structural features of molecular-colloidal solutions of $\mathrm{C}_{60}$ fullerenes in water by small-angle neutron scattering. Langmuir 20, 4363 (2004).

27. V.M. Garamus, G. Milkereit, S. Gerber et al. Micellar structure of a sugar based bolaamphiphile in pure solution and destabilizing effects in mixtures of glycolipids. Chem. Phys. Lett. 392, 105 (2004).

28. L.A.S.A. Prado, H. Wittich, K. Schulte et al. Anomalous small-angle X-ray scattering characterization of composites based on sulfonated poly(ether ether ketone), zirco- 
nium phosphates, and zirconium oxide. J. Polym. Sci. B 42, 567 (2004).

29. G. Milkereit, V.M. Garamus, K. Veermans et al. Synthesis and mesogenic properties of a Y-shaped glyco-glycerolipid. Chem. Phys. Lipids 131, 51 (2004).

30. M. Balasoiu, M.V. Avdeev, A.I. Kuklin et al. Structural studies of ferrofluids by small-angle neutron scattering. Magnetohydrodynamics 40, 359 (2004).

31. V. Pogorelov, L. Bulavin, I. Doroshenko et al. The structure of liquid alcohols and the temperature dependence of vibrational bandwidth. J. Mol. Struct. 708, 61 (2004).

32. L.A. Bastardo, V.M. Garamus, M. Bergstrom et al. The structures of complexes between polyethylene imine and sodium dodecyl sulfate in $\mathrm{D}_{2} \mathrm{O}$ : A scattering study. J. Phys. Chem. B 109, 167 (2005).

33. G. Milkereit, V.M. Garamus, J. Yamashita et al. Comparison of the supramolecular structures of two glyco lipids with chiral and nonchiral methyl-branched alkyl chains from natural sources. J. Phys. Chem. B 109, 1599 (2005).

34. L.M. Bergstrom, L.A. Bastardo, V.M. Garamus. A smallangle neutron and static light scattering study of micelles formed in aqueous mixtures of a nonionic alkylglucoside and an anionic surfactant. J. Phys. Chem. B 109, 12387 (2005).

35. C.A. Ericsson, O. Soderman, V.M. Garamus et al. Effects of temperature, salt, and deuterium oxide on the self-aggregation of alkylglycosides in dilute solution. 2. $n$ tetradecyl- $\beta$-d-maltoside. Langmuir 21, 1507 (2005).

36. G. Milkereit, V.M. Garamus, K. Veermans et al. Structures of micelles formed by synthetic alkyl glycosides with unsaturated alkyl chains. J. Colloid Interf. Sci. 284, 704 (2005).

37. L.A.S.A. Prado, M.L. Ponce, S.S. Funari et al. SAXS/WAXS characterization of proton-conducting polymer membranes containing phosphomolybdic acid. J. Non-Cryst. Solids 351, 2194 (2005).

38. G.P. Kopitsa, S.V. Grigoriev, V.V. Runov et al. Study of the heavy-fermion compound $\mathrm{CeRu}_{2} \mathrm{Si}_{2}$ by the smallangle neutron scattering method. JETP Lett. 81, 556 (2005).

39. G.P. Kopitsa, S.V. Grigoriev, V.V. Runov et al. Determining the structural parameters of fractal and nonfractal objects in multiple small-angle neutron scattering experiments. J. Exp. Theor. Phys. 101, 427 (2005).

40. G. Milkereit, V.M. Garamus. Complex effect of ethyl branching on the supramolecular structure of a long chain neoglycolipid. Colloids Surf. A 268, 155 (2005).

41. V.M. Garamus, G. Milkereit, R. Willumeit et al. How thermotropic properties influence the formation of lyotropic aggregates near the critical micelle concentration. J. Therm. Anal. Calorim. 82, 477 (2005).

42. Y.B. Melnichenko, G.D. Wignall, D.R. Cole et al. Liquidgas critical phenomena under confinement: small-angle neutron scattering studies of $\mathrm{CO}_{2}$ in aerogel. J. Mol. Liq. 120, 7 (2005)
43. V.Y. Starchenko, L.A. Bulavin, Y.P. Boiko et al. Conductometric and gravimetric studies of the kinetics of graphite sedimentation in aqueous dispersions. Colloid J. 67, 755 (2005).

44. I.L. Budyak, V. Pipich, O.S. Mironova et al. Shape and oligomerization state of the cytoplasmic domain of the phototaxis transducer II from Natronobacterium pharaonis. Proc. Natl. Acad. Sci. U.S.A. 103, 15428 (2006).

45. M. Balasoiu, M.V. Avdeev, V.L. Aksenov et al. Structural organization of water-based ferrofluids with sterical stabilization as revealed by SANS. J. Magn. Magn. Mater. 300, E225 (2006).

46. M.V. Avdeev, V.L. Aksenov, M. Balasoiu et al. Comparative analysis of the structure of sterically stabilized ferrofluids on polar carriers by small-angle neutron scattering. J. Colloid Interf. Sci. 295, 100 (2006).

47. M.V. Avdeev, T.V. Tropin, V.L. Aksenov et al. Pore structures in shungites as revealed by small-angle neutron scattering. Carbon 44, 954 (2006).

48. H. Kawasaki, V.M. Garamus, M. Almgren et al. Chargeinduced unilamellar vesicle formation and phase separation in solutions of di- $n$-decylmethylamine oxide. J. Phys. Chem. B 110, 10177 (2006).

49. M. Knaapila, L. Almasy, V.M. Garamus et al. Solubilization of polyelectrolytic hairy-rod polyfluorene in aqueous solutions of nonionic surfactant. J. Phys. Chem. B 110, 10248 (2006).

50. P.H. Thiesen, H. Rosenfeld, P. Konidala et al. Glycolipids from a colloid chemical point of view. J. Biotechnol. 124, 284 (2006).

51. M. Knaapila, V.M. Garamus, F.B. Dias et al. Influence of solvent quality on the self-organization of archetypical hairy rods-branched and linear side chain polyfluorenes: Rodlike chains versus "beta-sheets" in solution. Macromolecules 39, 6505 (2006).

52. A. Heins, V.M. Garamus, B. Steffen et al. Impact of phenolic antioxidants on structural properties of micellar solutions. Food Biophys. 1, 189 (2006).

53. A.A. Khokhryakov, O.A. Kyzyma, L.A. Bulavin et al. Colloidal structure and stabilization mechanism of aqueous solutions of unmodified fullerene $\mathrm{C}_{60}$. Crystallogr. Rep. 52, 487 (2007).

54. V.L. Aksenov, M.V. Avdeev, E.A. Kyzyma et al. Effect of the age of the $\mathrm{C}_{60} / \mathrm{N}$-methyl-2-pyrrolidone solution on the structure of clusters in the $\mathrm{C}_{60} / \mathrm{N}$-methyl-2-pyrrolidone/water system according to the small-angle neutron scattering data. Crystallogr. Rep. 52, 479 (2007).

55. G.P. Kopitsa, V.K. Ivanov, S.V. Grigoriev et al. Mesostructure of xerogels of hydrated zirconium dioxide. JETP Lett. 85, 122 (2007).

56. M. Almgren, V.M. Garamus, T. Asakawa et al. Contrast variation SANS investigation of composition distributions in mixed surfactant micelles. J. Phys. Chem. B 111, 7133 (2007).

ISSN 2071-0194. Ukr. J. Phys. 2020. Vol. 65, No. 8 
57. C. Sommer, G.R. Deen, J.S. Pedersen et al. Microemulsion droplets decorated by Brij700 block copolymer: Phase behavior and structural investigation by SAXS and SANS. Langmuir 23, 6544 (2007).

58. A. Meister, M. Bastrop, S. Koschoreck et al. Structureproperty relationship in stimulus-responsive bolaamphiphile hydrogels. Langmuir 23, 7715 (2007).

59. L.A. Bastardo, J. Iruthayaraj, M. Lundin et al. Soluble complexes in aqueous mixtures of low charge density comb polyelectrolyte and oppositely charged surfactant probed by scattering and NMR. J. Colloid Interf. Sci. 312, 21 (2007).

60. E.A. Krainova, M.V. Avdeev, K.V. Merkushina et al. Structural studies of a carbonizate obtained from solid cellulose-containing waste by sulfuric acid carbonization. Russ. J. Appl. Chem. 80, 1670 (2007).

61. S. Halacheva, S. Rangelov, V.M. Garamus. Structure and interactions in large compound particles formed by polyglycidol-based analogues to pluronic copolymers in aqueous solution. Macromolecules 40, 8015 (2007).

62. M. Knaapila, F.B. Dias, V.M. Garamus et al. Influence of side chain length on the self-assembly of hairy-rod poly(9,9-dialkylfluorene)s in the poor solvent methylcyclohexane. Macromolecules 40, 9398 (2007).

63. Yu. Plevachuk, V. Sklyarchuk, O. Alekhin et al. Experimental studies of phase equilibria in high-temperature ternary immiscible metallic melts. J. Non-Cryst. Solids 353, 3310 (2007).

64. O.A. Kyzyma, L.A. Bulavin, V.L. Aksenov et al. Aggregation in $\mathrm{C}_{60} / \mathrm{NMP}, \mathrm{C}_{60} / \mathrm{NMP} /$ water and $\mathrm{C}_{60} / \mathrm{NMP} /$ toluene mixtures. Fuller. Nanotub. Car. N. 16, 610 (2008).

65. L.J.R. Foster, D. Schwahan, V. Pipich et al. Smallangle neutron scattering characterization of polyhydroxyalkanoates and their bioPEGylated hybrids in solution. Biomacromolecules 9, 314 (2008).

66. F. Auriemma, C. De Rosa, R. Ricciardi et al. Time-resolving analysis of cryotropic gelation of water/poly(vinyl alcohol) solutions via small-angle neutron scattering. J. Phys. Chem. B 112, 816 (2008).

67. A. Meister, S. Drescher, I. Mey et al. Helical nanofibers of self-assembled bipolar phospholipids as template for gold nanoparticles. J. Phys. Chem. B 112, 4506 (2008).

68. M. Knaapila, V.M. Garamus, L. Almasy et al. Fractal aggregates of polyfluorene-polyaniline triblock copolymer in solution state. J. Phys. Chem. B 112, 16415 (2008).

69. V. Pipich, L. Willner, D. Schwahn. The A-B diblock copolymer as a nonordering external field in a threecomponent A/B/A-B polymer blend. J. Phys. Chem. B 112, 16170 (2008).

70. Y.-L. Li, M.-C. Maurel, C. Ebel et al. Self-association of adenine-dependent hairpin ribozymes. Eur. Biophys. J. 37, 173 (2008).

71. V. Pipich, M. Balz, S.E. Wolf et al. Nucleation and growth of $\mathrm{CaCO}_{3}$ mediated by the egg-white protein ovalbumin: A time-resolved in situ study using small-angle neutron scattering. J. Am. Chem. Soc. 130, 6879 (2008).
72. M. Knaapila, L. Almasy, V.M. Garamus et al. An effect of side chain length on the solution structure of poly(9,9dialkylfluorene)s in toluene. Polymer 49, 2033 (2008).

73. A. Meister, S. Drescher, V.M. Garamus et al. Temperature-dependent self-assembly and mixing behavior of symmetrical single-chain bolaamphiphiles. Langmuir 24, 6238 (2008).

74. J. Zbytovska, M.A. Kiselev, S.S. Funari et al. Influence of cholesterol on the structure of stratum corneum lipid model membrane. Colloids Surf. A 328, 90 (2008).

75. S. Rangelov, S. Halacheva, V.M. Garamus et al. Structural polymorphism exhibited by polyglycidol-based analogues to Pluronic copolymers in aqueous solution. Macromolecules 41, 8885 (2008).

76. Yu. Plevachuk, V. Sklyarchuk, O. Alekhin et al. Investigation of the critical region in monotectic systems by viscosity measurements. J. Phys. Conf. Ser. 98, 022007 (2008).

77. Yu. Plevachuk, V. Skliarchuk, O. Alekhin et al. Viscosity of liquid In-Se-Tl alloys in the miscibility gap region. J. Alloys Compd. 452, 174 (2008).

78. M.V. Avdeev, N.N. Rozhkova, V.L. Aksenov et al. Aggregate structure in concentrated liquid dispersions of ultrananocrystalline diamond by small-angle neutron scattering. J. Phys. Chem. C 113, 9473 (2009).

79. V.I. Petrenko, M.V. Avdeev, L. Almasy et al. Interaction of mono-carboxylic acids in benzene studied by smallangle neutron scattering. Colloids Surf. A 337, 91 (2009).

80. A.V. Feoktystov, L.A. Bulavin, M.V. Avdeev et al. Smallangle neutron scattering on magnetic fluids stabilized by monocarboxyl acids. Ukr. J. Phys. 54, 266 (2009).

81. A.V. Feoktystov, L.A. Bulavin, M.V. Avdeev et al. Smallangle neutron scattering by water-based ferrofluid mixed with polyethylene glycol. Ukr. J. Phys. 54, 348 (2009).

82. M.V. Avdeev, E. Dubois, G. Meriguet et al. Small-angle neutron scattering analysis of a water-based magnetic fluid with charge stabilization: contrast variation and scattering of polarized neutrons. J. Appl. Cryst. 42, 1009 (2009).

83. H.D. Burrows, M.J. Tapia, S.M. Fonseca et al. Aqueous solution behavior of anionic fluorene-co-thiophene-based conjugated polyelectrolytes. ACS Appl. Mater. Interfaces 1, 864 (2009).

84. S. Mukai, H. Miki, V. Garamus et al. Structural transition of non-ionic poly(acrylamide) gel. Progr. Colloid Polymer Sci. 136, 95 (2009).

85. V.K. Ivanov, G.P. Kopitsa, A.Ye. Baranchikov et al. Hydrothermal growth of ceria nanoparticles. Russ. J. Inorg. Chem. 54, 1857 (2009).

86. I. Adamenko, L. Bulavin, V. Korolovych et al. Thermophysical properties of carbon nanotubes in toluene under high pressure. J. Mol. Liq. 150, 1 (2009).

87. O.A. Kyzyma, M.V. Korobov, M.V. Avdeev et al. Aggregate development in $\mathrm{C}_{60} / \mathrm{N}$-methyl-2-pyrrolidone solution and its mixture with water as revealed by extraction and mass spectroscopy. Chem. Phys. Lett. 493, 103 (2010). 
88. M.V. Avdeev, T.V. Tropin, I.A. Bodnarchuk et al. On structural features of fullerene $\mathrm{C}_{60}$ dissolved in carbon disulfide: Complementary study by small-angle neutron scattering and molecular dynamic simulations. J. Chem. Phys. 132, 164515 (2010).

89. O.A. Kyzyma, M.V. Korobov, M.V. Avdeev et al. Solvatochromism and fullerene cluster formation in $\mathrm{C}_{60} / \mathrm{N}$ methyl-2-pyrrolidone. Fuller. Nanotub. Car. N. 18, 458 (2010).

90. T.V. Tropin, M.V. Avdeev, O.A. Kyzyma et al. Nucleation theory models for describing kinetics of cluster growth in C60/NMP solutions. Phys. Status Solidi B 247, 3022 (2010).

91. V.I. Petrenko, M.V. Avdeev, V.M. Garamus et al. Micelle formation in aqueous solutions of dodecylbenzene sulfonic acid studied by small-angle neutron scattering. Colloids Surf. A 369, 160 (2010).

92. G. Lancz, M.V. Avdeev, V.I. Petrenko et al. SANS study of poly(ethylene glycol) solutions in $\mathrm{D}_{2}$ O. Acta Phys. Pol. A 118, 980 (2010).

93. V.I. Petrenko, V.L. Aksenov, M.V. Avdeev et al. Analysis of the structure of aqueous ferrofluids by the smallangle neutron scattering method. Phys. Solid State 52, 974 (2010).

94. M.V. Avdeev, B. Mucha, K. Lamszus et al. Structure and in vitro biological testing of water-based ferrofluids stabilized by monocarboxylic acids. Langmuir 26, 8503 (2010).

95. M.V. Avdeev, A.V. Feoktystov, P. Kopcansky et al. Structure of water-based ferrofluids with sodium oleate and polyethylene glycol stabilization by small-angle neutron scattering: contrast-variation experiments. J. Appl. Cryst. 43, 959 (2010).

96. S. Halacheva, S. Rangelov, C. Tsvetanov et al. Aqueous solution properties of polyglycidol-based analogues of pluronic copolymers. Influence of the poly(propylene oxide) block molar mass. Macromolecules 43, 772 (2010).

97. J. Adelsberger, A. Kulkami, A. Jain et al. Thermoresponsive PS- $b$-PNIPAM- $b$-PS micelles: Aggregation behavior, segmental dynamics and thermal response. Macromolecules 43, 2490 (2010).

98. A. Heiss, V. Pipich, W. Jahnen-Dechent et al. Fetuin-A is a mineral carrier protein: Small angle neutron scattering provides new insight on fetuin-A controlled calcification inhibition. Biophys. J. 99, 3986 (2010).

99. A. Zou, J. Liu, V.M. Garamus et al. Micellization activity of the natural lipopeptide [Glu $\left.\mathrm{G}_{1}, \mathrm{Asp}_{5}\right]$ surfactin-C15 in aqueous solution. J. Phys. Chem. B 114, 2712 (2010).

100. K. Vogtt, C. Jeworrek, V.M. Garamus et al. Microdomains in lipid vesicles: Structure and distribution assessed by small-angle neutron scattering. J. Phys. Chem. B 114, 5643 (2010)

101. A. Zou, J. Liu, V.M. Garamus et al. Interaction between the natural lipopeptide $\left[\mathrm{Glu}_{1}, \mathrm{Asp}_{5}\right]$ surfactin-C15 and hemoglobin in aqueous solution. Biomacromolecules 11, 593 (2010).
102. M. Knaapila, R.C. Evans, A. Gutacker et al. Solvent dependent assembly of a polyfluorene-polythiophene "rodrod" block copolyelectrolyte: Influence on photophysical properties. Langmuir 26, 5056 (2010).

103. M. Knaapila, R.C. Evans, V.M. Garamus et al. Structure and "surfactochromic" properties of conjugated polyelectrolyte (CPE): Surfactant complexes between a cationic polythiophene and SDS in water. Langmuir 26, 15634 (2010).

104. V.K. Ivanov, G.P. Kopitsa, S.V. Grigoriev et al. Investigation of the evolution of the hydrated zirconia mesostructure at different stages of heat treatment. Phys. Solid State 52, 957 (2010).

105. L. He, H. Wang, V.M. Garamus et al. Analysis of monoPEGylated human galectin-2 by small-angle X-ray and neutron scattering: Concentration dependence of PEG conformation in the conjugate. Biomacromolecules 11, 3504 (2010).

106. B. Kent, C.J. Garvey, T. Lenne et al. Measurement of glucose exclusion from the fully hydrated DOPE inverse hexagonal phase. Soft Matter 6, 1197 (2010).

107. A. Meister, S. Drescher, G. Karlsson et al. Formation of square lamellae by self-assembly of long-chain bolaphospholipids in water. Soft Matter 6, 1317 (2010).

108. M. Balasoiu, L.A. Ischenko, S.V. Stolyar et al. Structural investigation of biogenic ferrihydrite nanoparticles dispersion. Optoelectron. Adv. Mat. 4, 2136 (2010).

109. L.A. Bulavin, V.I. Gordeliy, O.I. Ivankov et al. Neutron studies of the $\mathrm{NaBr}$ impurity influence on micelle formation in the heavy water-tetradecyltrimethylammonium bromide system. Ukr. J. Phys. 55, 288 (2010).

110. L.A. Bulavin, O.I. Ivankov, A.Kh. Islamov et al. Structure transformations in the triple liquid system tetradecyltrimethylammonium bromide- $\mathrm{D}_{2} \mathrm{O}-\mathrm{NaBr}$. Ukr. J. Phys. 55, 410 (2010).

111. L.A. Bulavin, O.I. Ivankov, V.M. Sysoev. Neutron research of the structure transition micelle to crystallites in liquid system $\mathrm{D}_{2} \mathrm{O}$-tetradecyltrimethilammonium bromide-NaBr. Yad. Fiz. Energet. 11, 86 (2010) (in Ukrainian).

112. Yu.P. Gomza, V.V. Klepko, S.V. Zhil'tsova et al. Structural and morphological features of organic-inorganic hybrid materials based on ethoxysilanes and epoxy resin. Polym. Sci. Ser. A 52, 628 (2010).

113. D.V. Soloviov, A.I. Kuklin, P.K. Utrobin et al. X-ray scattering and volumetric P-V-T studies of the dimyristoylphosphatidylcholine-water system. J. Surf. Invest. 5, 7 (2011).

114. O.V. Tomchuk, M.V. Avdeev, L.A. Bulavin et al. Smallangle neutron scattering by fractal clusters in aqueous dispersions of nanodiamonds. Phys. Part. Nucl. Lett. 8, 1046 (2011).

115. T.V. Tropin, M.V. Avdeev, O.A. Kyzyma et al. Towards description of kinetics of dissolution and cluster growth in $\mathrm{C}_{60}$ /NMP solutions. Phys. Status Solidi B 248, 2728 (2011).

ISSN 2071-0194. Ukr. J. Phys. 2020. Vol. 65, No. 8 
116. V. Zavisova, M. Koneracka, M. Muckova et al. Magnetic fluid poly(ethylene glycol) with moderate anticancer activity. J. Magn. Magn. Mater. 323, 1408 (2011).

117. R. Lund, V. Pipich, L. Willner et al. Structural and thermodynamic aspects of the cylinder-to-sphere transition in amphiphilic diblock copolymer micelles. Soft Matter 7, 1491 (2011).

118. M. Knaapila, R.C. Evans, A. Gutacker et al. Conjugated polyelectrolyte (CPE) poly[3-[6-(N-methylimidazolium)hexyl]-2,5-thiophene] complexed with aqueous sodium dodecylsulfateamphiphile: Synthesis, solution structure and "surfactochromic" properties. Soft Matter 7, 6863 (2011).

119. G. Mangiapia, M. Vaccaro, G. D'Errico et al. Cubosomes for ruthenium complex delivery: Formulation and characterization. Soft Matter 7, 10577 (2011).

120. R. Lund, L. Willner, V. Pipich et al. Equilibrium chain exchange kinetics of diblock copolymer micelles: Effect of morphology. Macromolecules 44, 6145 (2011).

121. M. Knaapila, D.W. Bright, B.S. Nehls et al. Development of intermolecular structure and beta-phase of random poly[9,9-bis(2-ethylhexyl)fluorene]-co-(9,9-dioctylfluorene) in methylcyclohexane. Macromolecules 44, 6453 (2011).

122. S. Halacheva, G.J. Price, V.M. Garamus. Effects of temperature and polymer composition upon the aqueous solution properties of comblike linear poly(ethylene imine)/poly(2-ethyl-2-oxazoline)-based polymers. Macromolecules 44, 7394 (2011).

123. S.E. Wolf, J. Leiterer, V. Pipich et al. Strong stabilization of amorphous calcium carbonate emulsion by ovalbumin: Gaining insight into the mechanism of 'polymer-induced liquid precursor' processes. J. Am. Chem. Soc. 133, 12642 (2011).

124. V.M. Nadutov, S.G. Kosintsev, Ye.O. Svystunov et al. Anti-Invar properties and magnetic order in fcc $\mathrm{Fe}-\mathrm{Ni}-\mathrm{C}$ alloy. J. Magn. Magn. Mater. 323, 2786 (2011).

125. S.A. Samoylenko, S.E. Kichanov, A.V Belushkin et al. The studies of structural aspects of the cluster formation in silicate glasses doped with cerium and titanium oxides by small-angle neutron scattering. Phys. Solid State 53, 2431 (2011).

126. M.V. Avdeev, N.M. Blagoveshchenskii, V.M. Garamus et al. Investigation of the tripoli porous structure by small-angle neutron scattering. Crystallogr. Rep. 56, 1090 (2011).

127. T. Zheltonozhskaya, V. Nedashkovskaya, V. Khutoryanskiy et al. Micelles of PAAm- $b$-PEO- $b$-PAAm triblock copolymers and their binding with prednisolon Mol. Cryst. Liq. Cryst. 536, 148 (2011).

128. N.I. Lebovka, E.A. Lysenkov, A.I. Goncharuk et al. Phase behaviour, microstructure, and percolation of poly(ethylene glycol) filled by multiwalled carbon nanotubes and organophilic montmorillonite. J. Compos. Mater. 45, 2555 (2011).

129. L.A. Bulavin, N.I. Lebovka, Yu.A. Kyslyi et al. Microstructural, rheological, and conductometric studies of multiwalled carbon nanotube suspensions in glycerol. Ukr. J. Phys. 56, 217 (2011).

130. O.V. Tomchuk, M.V. Avdeev, V.L. Aksenov et al. Comparative structural characterization of the water dispersions of detonation nanodiamonds by small-angle neutron scattering. J. Surf. Invest. 6, 821 (2012).

131. O.B. Karpenko, V.V. Trachevskij, O.V. Filonenko et al. NMR study of non-equilibrium state of fullerene $\mathrm{C}_{60}$ in N-methyl-2-pyrrolidone. Ukr. J. Phys. 57, 860 (2012).

132. T.O. Kyrey, O.A. Kyzyma, M.V. Avdeev et al. Absorption characteristics of fullerene $\mathrm{C}_{60}$ in N-methyl-2pirrolidone/toluene mixture. Fuller. Nanotub. Car. N. 20, 341 (2012).

133. T.V. Tropin, N. Jargalan, M.V. Avdeev et al. Kinetics of cluster growth in polar solutions of fullerene: Experimental and theoretical study of $\mathrm{C}_{60} / \mathrm{NMP}$ solution. J. Mol. Liq. 175, 4 (2012).

134. V.I. Petrenko, M.V. Avdeev, L.A. Bulavin et al. Diagnostic and analysis of aggregation stability of magnetic fluids for biomedical applications by small-angle neutron scattering. J. Phys. Conf. Ser. 345, 012028 (2012).

135. F. Zhang, F. Roosen-Runge, M.W.A. Skoda et al. Hydration and interactions in protein solutions containing concentrated electrolytes studied by small-angle scattering. Phys. Chem. Chem. Phys. 14, 2483 (2012).

136. D. Schwahn, V. Pipich, D. Richter. Composition and long-range density fluctuations in $\mathrm{PEO} / \mathrm{PMMA}$ polymer blends: A result of asymmetric component mobility. Macromolecules 45, 2035 (2012).

137. A. Meier-Koll, V. Pipich, P. Busch et al. Phase separation in semidilute aqueous poly(N-isopropylacrylamide) solutions. Langmuir 28, 8791 (2012).

138. D.V. Soloviov, Yu.E. Gorshkova, O.I. Ivankov et al. Ripple phase behavior in mixtures of DPPC/POPC lipids: SAXS and SANS studies. J. Phys. Conf. Ser. 351, 012010 (2012).

139. S.E. Kichanov, D.P. Kozlenko, A.V. Belushkin et al. A study of formation of iron nanoparticles in aluminium matrix with helium pores. J. Phys. Conf. Ser. 351, 012013 (2012).

140. S.A. Samoylenko, S.E. Kichanov, D.P. Kozlenko et al. The studies of nanoparticles formed in silicate glasses doped by cerium and titanium oxides by means of small angle neutron scattering. J. Phys. Conf. Ser. 351, 012017 (2012).

141. M.-L. Craus, E. Anitas, N. Cornei et al. Magnetic structure of $\mathrm{La}_{0.54} \mathrm{Ho}_{0.11} \mathrm{Sr}_{0.35} \mathrm{Mn}_{1-x} \mathrm{Cu}_{x} \mathrm{O}_{3}$ manganites. Solid State Phenom. 190, 121 (2012).

142. M. Stepanek, J. Skvarla, M. Uchman et al. Wormlike core-shell nanoparticles formed by co-assembly of double hydrophilic block polyelectrolyte with oppositely charged fluorosurfactant. Soft Matter 8, 9412 (2012).

143. I.G. Chuvashova, A.S. Vanetsev, O.M. Gaitko et al. Effect of synthesis conditions of the micro- and mesostructure of monodisperse $\mathrm{Y}(\mathrm{OH}) \mathrm{CO}_{3}$ powders. Doklady Chemistry 446, 207 (2012).

144. D.V. Soloviov, L.A. Bulavin, V.I. Gordeliy et al. Neutron scattering investigations of the lipid bilayer structure 
pressure dependence. Yad. Fiz. Energet. 13, 83 (2012) (in Ukrainian).

145. L.A. Bulavin, D.V. Solov'ev, Yu.E. Gorshkova et al. Structural transition in a lipid-water liquid system. $U k r$. J. Phys. 57, 623 (2012).

146. E.A. Lysenkov, N.I. Lebovka, Y.V. Yakovlev et al. Percolation behaviour of polypropylene glycol filled with multiwalled carbon nanotubes and Laponite. Compos. Sci. Technol. 72, 1191 (2012).

147. M.V. Avdeev, V.L. Aksenov, O.V. Tomchuk et al. The spatial diamond-graphite transition in detonation nanodiamond as revealed by small-angle neutron scattering. J. Phys.: Cond. Matt. 25, 445001 (2013).

148. A.A. Kaznacheevskaya, O.A. Kizima, L.A. Bulavin et al. Reorganization of the cluster state in a $\mathrm{C}_{60} / \mathrm{N}$-methylpyrrolidone/water solution: Comparative characteristics of dynamic light scattering and small-angle neutron scattering data. J. Surf. Invest. 7, 1133 (2013).

149. A.V. Nagornyi, V.I. Petrenko, M.V. Avdeev et al. On determination of the structural parameters of polydisperse magnetic fluids by small-angle neutron scattering. J. Surf. Invest. 7, 99 (2013).

150. O.A. Kyzyma, T.O. Kyrey, M.V. Avdeev et al. Non-reversible solvatochromism in N-methyl-2-pyrrolidone/toluene mixed solutions of fullerene $\mathrm{C}_{60}$. Chem. Phys. Lett. 556, 178 (2013).

151. T.V. Tropin, T.O. Kyrey, O.A. Kyzyma et al. Experimental investigation of $\mathrm{C}_{60} / \mathrm{NMP} /$ toluene solutions by $\mathrm{UV}$ Vis spectroscopy and small-angle neutron scattering. $J$. Surf. Invest. 7, 1 (2013).

152. M.V. Avdeev, V.L. Aksenov, Z. Gazova et al. On the determination of the helical structure parameters of amyloid protofilaments by small-angle neutron scattering and atomic force microscopy. J. Appl. Cryst. 46, 224 (2013).

153. V.I. Petrenko, M.V. Avdeev, R. Turcu et al. Powder structure of magnetic nanoparticles with a substituted pyrrole copolymer shells according to small-angle neutron scattering. J. Surf. Invest. 7, 5 (2013).

154. R.A. Eremin, K. Kholmurodov, V.I. Petrenko et al. Effect of the solute-solvent interface on small-angle neutron scattering from organic solutions of short alkyl chain molecules as revealed by molecular dynamics simulation. J. Appl. Cryst. 46, 372 (2013).

155. M. Golub, D. Lott, E.B. Watkins et al. X-ray and neutron investigation of self-assembled lipid layers on a titanium surface. Biointerphases 8, 21 (2013).

156. G. Graf, S. Drescher, A. Meister et al. Bolalipid fiber aggregation can be modulated by the introduction of sulfur atoms into the spacer chains. J. Colloid Interf. Sci. 393, 143 (2013).

157. S.E. Dem'yanov, N.A. Kalanda, L.V. Kovalev et al. Dielectric barrier formation and tunneling magnetoresistance effect in strontium iron molybdate. Tech. Phys. Lett. 39, 552 (2013).

158. X. Yang, L. Zhao, L. Almasy et al. Preparation and characterization of 4-dedimethylamino sancycline (CMT-3) loaded nanostructured lipid carrier (CMT-3/NLC) formulations. Int. J. Pharm. 450, 225 (2013).

159. J. Liu, M. Harms, V.M. Garamus et al. Reentrant structural phase transition in amphiphilic self-assembly. Soft Matter 9, 6371 (2013).

160. G. Graf, S. Drescher, A. Meister et al. Tuning the aggregation behaviour of single-chain bolaamphiphiles in aqueous suspension by changes in headgroup asymmetry. Soft Matter 9, 9562 (2013).

161. V.F. Korolovych, S.P. Nedyak, K.O. Moroz et al. Compressibility of water containing single-walled carbon nanotubes. Fuller. Nanotub. Car. N. 21, 24 (2013).

162. V. Savenko, L. Bulavin, M. Rawiso et al. Sedimentation stability and aging of aqueous dispersions of Laponite in the presence of cetyltrimethylammonium bromide. Phys. Rev. E 88, 052301 (2013).

163. M.E. Kornienko, N.L. Sheiko, O.M. Kornienko et al. Discrete properties of quasiliquidwater film in the ice premelting range. 1. Temperature dependences of water nanofilm thickness and viscoelasticproperties of polycrystalline ice. Ukr. J. Phys. 58, 151 (2013).

164. E.A. Lysenkov, Yu.V. Yakovlev, V.V. Klepko et al. Percolation propertiesof systems based on polypropyleneglycol and carbon nanotubes. Ukr. J. Phys. 58, 378 (2013).

165. A.V. Chalyi, L.A. Bulavin, V.F. Chekhun et al. Universality classes and critical phenomena in confined liquid systems. Condens. Matter Phys. 16, 23008 (2013).

166. A.V. Nagornyi, L.A. Bulavin, V.I. Petrenko et al. Determination of the structure factor of interparticle interactions in the ferrofluid by small-angle neutron scattering. Nucl. Phys. At. Energy 15, 59 (2014).

167. L.A. Bulavin, V.S. Savenko, N.I. Lebovka et al. Smallangle neutron scattering of multiwalled carbon nanotubes in aqueous suspensions in presence of Laponite platelets or cetyltrimethylammonium bromide. Yad. Fiz. Energet. 14, 372 (2013) (in Ukrainian).

168. T.V. Tropin, N. Jargalan, M.V. Avdeev et al. Calculation of the cluster size distribution functions and small-angle neutron scattering data for $\mathrm{C}_{60} / \mathrm{N}$-methylpyrrolidone. Phys. Solid State 56, 148 (2014).

169. Y.I. Prylutskyy, V.I. Petrenko, O.I. Ivankov et al. On the origin of $\mathrm{C}_{60}$ fullerene solubility in aqueous solution. Langmuir 30, 3967 (2014).

170. L. Melnikova, Z. Mitroova, M. Timko et al. Structural characterization of magnetoferritin. Mendeleev Commun. 24, 80 (2014).

171. V. Petrenko, L. Bulavin, M. Avdeev et al. Structure and interaction of poly(ethylene glycol) in aqueous solutions. Small-angle neutron scattering data. Macromol. Symp. 335, 20 (2014).

172. V.I. Petrenko, M.V. Avdeev, V.M. Garamus et al. Structure of amyloid aggregates of lysozyme from small-angle X-ray scattering data. Phys. Solid State 56, 129 (2014).

173. L. Melnikova, V.I. Petrenko, M.V. Avdeev et al. Effect of iron oxide loading on magnetoferritin structure in solution as revealed by SAXS and SANS. Colloids Surf. B 123, 82 (2014).

ISSN 2071-0194. Ukr. J. Phys. 2020. Vol. 65, No. 8 
174. S.E. Kichanov, A.Kh. Islamov, S.A. Samoilenko et al. Studying the structural features of oxide nanoclusters of cerium and titanium in a silicate glass by means of the small-angle neutron scattering. J. Surf. Invest. 8, 98 (2014).

175. N.N. Gubanova, G.P. Kopitsa, K.V. Ezdakova et al. Structure of zirconium dioxide based porous glasses. J. Surf. Invest. 8, 967 (2014).

176. S. Goossen, A.R. Bras, M. Krutyeva et al. Molecular scale dynamics of large ring polymers. Phys. Rev. Lett. 113, 168302 (2014).

177. Y.N. Dahdal, V. Pipich, H. Rapaport et al. Smallangle neutron scattering studies of mineralization on BSA coated citrate capped gold nanoparticles used as a model surface for membrane scaling in RO wastewater desalination. Langmuir 30, 15072 (2014).

178. F. Schneider, A. Balaceanu, A. Feoktystov et al. Monitoring the internal structure of poly(N-vinylcaprolactam) microgels with variable cross-link concentration. Langmuir 30, 15317 (2014).

179. A. Accardo, P. Ringhieri, N. Szekely et al. Structural insights on nanoparticles containing gadolinium complexes as potential theranostic. Colloid Polym. Sci. 292, 1121 (2014).

180. S. Jaksch, A. Schulz, K. Kyriakos et al. The collapse and aggregation of thermoresponsive poly(2-oxazoline) gradient copolymers: a time-resolved SANS study. Colloid Polym. Sci. 292, 2413 (2014).

181. M. Helminger, B. Wu, T. Kollmann et al. Synthesis and characterization of gelatin-based magnetic hydrogels. Adv. Funct. Mater. 24, 3187 (2014).

182. T. Zinn, L. Willner, R. Lund et al. Surfactant or block copolymer micelles? Structural properties of a series of well-defined $n$-alkyl-PEO micelles in water studied by SANS. Soft Matter 10, 5212 (2014).

183. S. Drescher, A. Meister, V.M. Garamus et al. Phenylene bolaamphiphiles: Influence of the substitution pattern on the aggregation behavior and the miscibility with classical phospholipids. Eur. J. Lipid Sci. Technol. 116, 1205 (2014).

184. T. Gorniak, T. Haraszti, V.M. Garamus et al. Nano-scale morphology of melanosomes revealed by small-angle Xray scattering. PLoS One 9, e90884 (2014).

185. J. Xiao, F. Liu, V.M. Garamus et al. Insights into the interactions among surfactin, betaines, and PAM: Surface tension, small-angle neutron scattering, and small-angle X-ray scattering study. Langmuir 30, 3363 (2014).

186. S. Zhao, X. Yang, V.M. Garamus et al. Mixture of nonionic/ionic surfactants for the formulation of nanostructured lipid carriers: Effects on physical properties. Langmuir 30, 6920 (2014).

187. S. Drescher, B.-D. Lechner, V.M. Garamus et al. The headgroup (A)symmetry strongly determines the aggregation behavior of single-chain phenylene-modified bolalipids and their miscibility with classical phospholipids. Langmuir 30, 9273 (2014).
188. M. Knaapila, T. Costa, V.M. Garamus et al. Conjugated polyelectrolyte (CPE) poly3-[6-(N-methylimidazolium)hexyl]-2,5-thiophene complexed with DNA: Relation between colloidal level solution structure and chromic effects. Macromolecules 47, 4017 (2014).

189. Y. Chen, X. Yang, L. Zhao et al. Preparation and characterization of a nanostructured lipid carrier for a poorly soluble drug. Colloids Surf. A 455, 36 (2014).

190. J. Hajduova, K. Prochazka, V. Raus et al. Structure of polymeric nanoparticles in surfactant-stabilized aqueous dispersions of high-molar-mass hydrophobic graft copolymers. Colloids Surf. A 456, 10 (2014).

191. D. Soloviov, Yu. Zabashta, L. Bulavin et al. Changes in the area per lipid molecule by $\mathrm{P}-\mathrm{V}-\mathrm{T}$ and SANS investigations. Macromol. Symp. 335, 58 (2014).

192. V.F. Korolovych, L.A. Bulavin, Yu.I. Prylutskyy et al. Influence of single-walled carbon nanotubes on thermal expansion of water. Int. J. Thermophys. 35, 19 (2014).

193. V. Savenko, L. Bulavin, M. Rawiso et al. Aging of aqueous Laponite dispersions in the presence of sodium polystyrene sulfonate. Ukr. J. Phys. 59, 589 (2014).

194. O. Deriabina, N. Lebovka, L. Bulavin et al. Regulation of dispersion of carbon nanotubes in binary water +1 -cyclohexyl-2-pyrrolidone mixtures. Physica E 59, 150 (2014).

195. L.A. Bulavin, D.V. Soloviov, V.I. Gordeliy et al. Lyotropic model membrane structures of hydrated DPPC: DSC and small-angle X-ray scattering studies of phase transitions in the presence of membranotropic agents. Phase Transit. 88, 582 (2015).

196. O.V. Tomchuk, D.S. Volkov, L.A. Bulavin et al. Structural characteristics of aqueous dispersions of detonation nanodiamond and their aggregate fractions as revealed by small-angle neutron scattering. J. Phys. Chem. C $\mathbf{1 1 9}$ 794 (2015).

197. L.A. Bulavin, S.O. Samoilenko, S.E. Kichanov et al. Nanoformation in doped silicate glass and its fractal dimensions. Yad. Fiz. Energet. 16, 152 (2015) (in Ukrainian).

198. L.A. Bulavin, O.V. Tomchuk, M.V. Avdeev. Investigation of the cluster structure in aqueous suspensions of nanodiamonds by small-angle neutron scattering. Yad. Fiz. Energet. 16, 198 (2015).

199. L.A. Bulavin, Yu.F. Zabashta. Anomalous asymptoticof small-angle neutron scattering intensity. Ukr. J. Phys. 60, 314 (2015).

200. M.V. Avdeev, V.I. Petrenko, A.V. Feoktystov et al. Neutron investigations of ferrofluids. Ukr. J. Phys. 60, 728 (2015).

201. O.A. Kyzyma, A.V. Tomchuk, M.V. Avdeev et al. Structural researches of carbonic fluid nanosystems. Ukr. J. Phys. 60, 835 (2015).

202. L.A. Bulavin, D.V. Soloviov, A.I. Kuklin et al. Smallangle X-ray scattering and differential scanning calorimetry studies of DPPC multilamellar structures containing membranotropic agents of different chemical nature. $U k r$. J. Phys. 60, 905 (2015).

203. N.I. Lebovka, L.A. Bulavin, I.A. Melnyk et al. Impact of aggregation on the percolation anisotropy on a square 
lattice in an elongated geometry. Ukr. J. Phys. 60, 910 (2015).

204. V.V. Strelchuk, A.S. Nikolenko, Yu.Yu. Stubrov et al. Phonon energy spectra and stationary elastic waves in single-walled carbon nanotubes and graphite bulk crystals. Ukr. J. Phys. 60, 925 (2015).

205. V.V. Klepko, E.A. Lysenkov. Features of percolation transition in systems on the basis of oligoglycols and carbon nanotubes. Ukr. J. Phys. 60, 944 (2015).

206. E.A. Kyzyma, A.A. Tomchuk, L.A. Bulavin et al. Structure and toxicity of aqueous fullerene $\mathrm{C}_{60}$ solutions. J. Surf. Invest. 9, 1 (2015).

207. Y.I. Prylutskyy, M.P. Evstigneev, V.V. Cherepanov et al. Structural organization of $\mathrm{C}_{60}$ fullerene, doxorubicin, and their complex in physiological solution as promising antitumor agents. J. Nanopart. Res. 17, 45 (2015).

208. Yu.I. Prylutskyy, V.V. Cherepanov, M.P. Evstigneev et al. Structural self-organization of $\mathrm{C}_{60}$ and cisplatin in physiological solution. Phys. Chem. Chem. Phys. 17, 26084 (2015).

209. L. Melnikova, V.I. Petrenko, M.V. Avdeev et al. SANS contrast variation study of magnetoferritin structure at various iron loading. J. Magn. Magn. Mater. 377, 77 (2015).

210. P. Kopcansky, K. Siposova, L. Melnikova et al. Destroying activity of magnetoferritin on lysozyme amyloid fibrils. J. Magn. Magn. Mater. 377, 267 (2015).

211. R. Turcu, I. Craciunescu, V.M. Garamus et al. Magnetic microgels for drug targeting applications: Physicalchemical properties and cytotoxicity evaluation. J. Magn. Magn. Mater. 380, 307 (2015).

212. M. Rajnak, V.I. Petrenko, M.V. Avdeev et al. Direct observation of electric field induced pattern formation and particle aggregation in ferrofluids. Appl. Phys. Lett. 107, 073108 (2015).

213. V.I. Petrenko, M.V. Avdeev, V.M. Garamus et al. Impact of polyethylene glycol on aqueous micellar solutions of sodium oleate studied by small-angle neutron scattering. Colloids Surf. A 480, 191 (2015).

214. A. Sauter, F. Roosen-Runge, F. Zhang et al. On the question of two-step nucleation in protein crystallization. Faraday Discuss. 179, 41 (2015).

215. M. Siglreitmeier, B. Wu, T. Kollmann et al. Multifunctional layered magnetic composites. Beilstein J. Nanotechnol. 6, 134 (2015)

216. M. Knaapila, T. Costa, V.M. Garamus et al. Polyelectrolyte complexes of a cationic all conjugated fluorenethiophene diblock copolymer with aqueous DNA. J. Phys. Chem. B 119, 3231 (2015).

217. M. Wang, T. Zander, X. Liu et al. The effect of temperature on supported dipalmitoylphosphatidylcholine (DPPC) bilayers: Structure and lubrication performance. J. Colloid Interf. Sci. 445, 84 (2015).

218. A. Jaeger, E. Jaeger, F. Surman et al. Nanoparticles of the poly([N-(2-hydroxypropyl)]methacrylamide)b-poly[2-(diisopropylamino)ethyl methacrylate] diblock copolymer for $\mathrm{pH}$-triggered release of paclitaxel. Polym. Chem. 6, 4946 (2015).

219. Y. Chen, A. Angelova, B. Angelov et al. Sterically stabilized spongosomes for multidrug delivery of anticancer nanomedicines. J. Mater. Chem. B 3, 7734 (2015).

220. S.K. Filippov, O.Yu. Sergeeva, P.S. Vlasov et al. Modified hydroxyethyl starch protects cells from oxidative damage. Carbohydr. Polym. 134, 314 (2015).

221. M. Balasoiu, O.I. Ivankov, D.V. Soloviov et al. Microstructure investigation of a $\mathrm{CoFe}_{2} \mathrm{O}_{4}$ /lauric acid/DDS$\mathrm{Na} / \mathrm{H}_{2} \mathrm{O}$ ferrofluid. J. Optoelectron. Adv. M. 17, 1114 (2015).

222. T.N. Murugova, A.V. Vlasov, O.I. Ivankov et al. Low resolution structural studies of apoferritin via SANS and SAXS: the effect of concentration. J. Optoelectron. Adv. M. 17, 1397 (2015).

223. H. Gibhardt, C.R. Haramagatti, A.Kh. Islamov et al. Ordering phenomena in surfactant systems: From micellar solutions to gel and crystalline phases. Z. Phys. Chem. 229, 1869 (2015).

224. T.B. Feldman, O.I. Ivankov, T.N. Murugova et al. Study of visual pigment rhodopsin supramolecular organization in photoreceptor membrane by small-angle neutron scattering method with contrast variation. Dokl. Biochem. Biophys. 465, 420 (2015).

225. D.M. Nozdrenko, K.I. Bogutska, Yu.I. Prylutskyy et al. Impact of $\mathrm{C}_{60}$ fullerene on the dynamics of force-speed changes in soleus muscle of rat at ischemia-reperfusion injury. Fiziol. Zh. 61, 48 (2015).

226. E.A. Lysenkov, Z.O. Gagolkina, E.V. Lobko et al. Structure-property relationships in polymer nanocomposites based on cross-linked polyurethanes and carbon nanotubes. Funct. Mater. 22, 342 (2015).

227. E. Lysenkov, I. Melnyk, L. Bulavin et al. Structure of polyglycols doped by nanoparticles with anisotropic shape. In: Proceedings of the Conference "Physics of Liquid Matter: Modern Problems", Kyiv, Ukraine, 23-27 May 2014, edited by L. Bulavin, N. Lebovka (Springer, 2015), p. 165.

228. K.M. Sukhyy, Yu.P. Gomza, E.A. Belyanovskaya et al. Resistive humidity sensors based on proton-conducting organic-inorganic silicophosphates doped by polyionenes. J. Sol-Gel Sci. Technol. 74, 472 (2015).

229. L.A. Bulavin, L.Yu. Vergun, Yu.F. Zabashta et al. Largescaled clusters in aqueous glucose solutions. Colloid J. 77, 261 (2015).

230. M.V. Avdeev, O.V. Tomchuk, O.I. Ivankov et al. On the structure of concentrated detonation nanodiamond hydrosols with a positive $\zeta$ potential: Analysis of small-angle neutron scattering. Chem. Phys. Lett. 658, 58 (2016).

231. A.V. Nagornyi, V.I. Petrenko, M.V. Avdeev et al. Structure of water-based magnetic liquids by small-angle X-ray scattering. Roman. J. Phys. 61, 483 (2016).

232. V. Dordovic, M. Uchman, M. Reza et al. Cationsensitive compartmentalization in metallacarborane containing polymer nanoparticles. RSC Adv. 6, 9884 (2016). 
233. Y.I. Prylutskyy, V.V. Cherepanov, V.V. Kostjukov et al. Study of the complexation between Landomycin A and $\mathrm{C}_{60}$ fullerene in aqueous solution. $R S C A d v$. 6, 81231 (2016).

234. Yu.V. Kulvelis, S.S. Ivanchev, O.N. Primachenko et al. Structure and property optimization of perfluorinated short side chain membranes for hydrogen fuel cells using orientational stretching. RSC Adv. 6, 108864 (2016).

235. Y. Prylutskyy, A. Borowik, G. Golunski et al. Biophysical characterization of the complexation of $\mathrm{C}_{60}$ fullerene with doxorubicin in a prokaryotic model. Materialwiss. Werkst. 47, 92 (2016).

236. A.D. Yapryntsev, N.N. Gubanova, G.P. Kopitsa et al. Mesostructure of yttrium and aluminum basic salts coprecipitated from aqueous solutions under ultrasonic treatment. J. Surf. Invest. 10, 177 (2016).

237. S.O. Samoilenko, S.E. Kichanov, D.P. Kozlenko et al. Study of silicate glasses with $\mathrm{PbS}$ nanoparticles using small-angle neutron scattering. J. Surf. Invest. 10, 187 (2016).

238. E.A. Kyzyma, M.O. Kuzmenko, L.A. Bulavin et al. Impact of a physiological medium on the aggregation state of $\mathrm{C}_{60}$ and $\mathrm{C}_{70}$ fullerenes. J. Surf. Invest. 10, 1125 (2016).

239. J. Majorosova, V.I. Petrenko, K. Siposova et al. On the adsorption of magnetite nanoparticles on lysozyme amyloid fibrils. Colloids Surf. B 146, 794 (2016).

240. Z. Fu, Y. Xiao, A. Feoktystov et al. Field-induced selfassembly of iron oxide nanoparticles investigated using small-angle neutron scattering. Nanoscale 8, 18541 (2016).

241. Y.N. Dahdal, V. Pipich, H. Rapaport et al. Small-angle neutron scattering studies of alginate as biomineralizing agent and scale initiator. Polymer 85, 77 (2016).

242. A. Sauter, F. Zhang, N.K. Szekely et al. Structural evolution of metastable protein aggregates in the presence of trivalent salt studied by (V)SANS and SAXS. J. Phys. Chem. B 120, 5564 (2016).

243. N. Kampman, A. Busch, P. Bertier et al. Observational evidence confirms modelling of the long-term integrity of $\mathrm{CO}_{2}$-reservoir caprocks. Nat. Commun. 7, 12268 (2016).

244. Y.V. Kuznetsova, A.A. Rempel, M. Meyer et al. Small angle X-ray and neutron scattering on cadmium sulfide nanoparticles in silicate glass. J. Cryst. Growth 447, 13 (2016).

245. D. Schwahn, V. Pipich, R. Kasher et al. Accumulation of $\mathrm{GdCl}_{3}$ in the feed of a reverse osmosis system during desalination as determined by neutron absorption. J. Phys. Conf. Ser. 746, 012039 (2016)

246. E.P. Simonenko, N.P. Simonenko, G.P. Kopitsa et al. How xerogel carbonization conditions affect the reactivity of highly disperse $\mathrm{SiO}_{2}-\mathrm{C}$ composites in the sol-gel synthesis of nanocrystalline silicon carbide. Russ. J. Inorg. Chem. 61, 1347 (2016).

247. D. Schwahn, V. Pipich. Aqueous solutions of poly(ethylene oxide): Crossover from ordinary to tricritical behavior. Macromolecules 49, 8228 (2016).
248. A. Radulescu, N.K. Szekely, M.-S. Appavou et al. Studying soft-matter and biological systems over a wide lengthscale from nanometer and micrometer sizes at the smallangle neutron diffractometer KWS-2. J. Vis. Exp. 2016 e54639 (2016).

249. M. Golub, D. Lott, V.M. Garamus et al. Neutron study of phospholipids 1-palmitoyl-2-oleoyl-sn-glycero-3-phosphoethanolamine spray coating on titanium implants. Biointerphases 11, 011002 (2016).

250. A. Riabtseva, N. Mitina, I. Grytsyna et al. Functional micelles formed by branched polymeric surfactants: Synthesis, characteristics, and application as nanoreactors and carriers. Eur. Polym. J. 75, 406 (2016).

251. T. Zander, D.C.F. Wieland, A. Raj et al. The influence of hyaluronan on the structure of a DPPC-bilayer under high pressures. Colloids Surf. B 142, 230 (2016).

252. A.R. von Gundlach, V.M. Garamus, T. Gorniak et al. Small angle X-ray scattering as a high-throughput method to classify antimicrobial modes of action. Biochim. Biophys. Acta 1858, 918 (2016)

253. W. Lv, S. Zhao, H. Yu et al. Brucea javanica oil-loaded nanostructure lipid carriers (BJO NLCs): Preparation, characterization and in vitro evaluation. Colloids Surf. A 504, 312 (2016).

254. L. Jin, V.M. Garamus, F. Liu et al. Interaction of a biosurfactant, Surfactin with a cationic Gemini surfactant in aqueous solution. J. Colloid Interf. Sci. 481, 201 (2016).

255. M. Zhernenkov, D. Bolmatov, D. Soloviov et al. Revealing the mechanism of passive transport in lipid bilayers via phonon-mediated nanometre-scale density fluctuations. Nat. Commun. 7, 11575 (2016).

256. L. Bulavin, N. Kutsevol, V. Chumachenko et al. SAXS combined with UV-vis spectroscopy and QELS: Accurate characterization of silver sols synthesized in polymer matrices. Nanoscale Res. Lett. 11, 35 (2016).

257. C. Stan, M. Balasoiu, A.I. Ivankov et al. Multifractal analysis of $\mathrm{CoFe}_{2} \mathrm{O}_{4} / 2 \mathrm{DBS} / \mathrm{H}_{2} \mathrm{O}$ ferrofluid from TEM and SANS measurements. Roman. Rep. Phys. 68, 270 (2016).

258. V.F. Korolovych, O.A. Grishina, O.A. Inozemtseva et al. Impact of high-frequency ultrasound on nanocomposite microcapsules: in silico and in situ visualization. Phys. Chem. Chem. Phys. 18, 2389 (2016).

259. W. Xu, A.A. Steinschulte, F.A. Plamper et al. Hierarchical assembly of star polymer polymersomes into responsive multicompartmental microcapsules. Chem. Mater. 28, 975 (2016).

260. M. Tolkachov, V. Sokolova, K. Loza et al. Study of biocompatibility effect of nanocarbon particles on various cell types in vitro. Materialwiss. Werkst. 47, 216 (2016).

261. V.F. Korolovych, P.A. Ledin, A. Stryutsky et al. Assembly of amphiphilic hyperbranched polymeric ionic liquids in aqueous media at different $\mathrm{pH}$ and ionic strength. Macromolecules 49, 8697 (2016).

262. M.V. Avdeev, V.I. Bodnarchuk, V.I. Petrenko et al. Neutron time-of-flight reflectometer GRAINS with horizon- 
tal sample plane at the IBR-2 reactor: Possibilities and prospects. Crystallogr. Rep. 62, 1002 (2017).

263. M.V. Avdeev, A.A. Rulev, V.I. Bodnarchuk et al. Monitoring of lithium plating by neutron reflectometry. Appl. Surf. Sci. 424, 378 (2017).

264. A.V. Nagornyi, V.I. Petrenko, M.V. Avdeev et al. Structural aspects of magnetic fluid stabilization in aqueous agarose solutions. J. Magn. Magn. Mater. 431, 16 (2017).

265. T.V. Nagorna, O.A. Kyzyma, D. Chudoba et al. Temporal solvatochromic effect in ternary $\mathrm{C}_{70} /$ toluene/N-methylpyrrolidine-2-one solution. J. Mol. Liq. 235, 111 (2017).

266. Y.I. Prylutskyy, I.V. Vereshchaka, A.V. Maznychenko et al. $\mathrm{C}_{60}$ fullerene as promising therapeutic agent for correcting and preventing skeletal muscle fatigue. J. Nanobiotechnol. 15, 8 (2017).

267. S. Prylutska, R. Panchuk, G. Golunski et al. $\mathrm{C}_{60}$ fullerene enhances cisplatin anticancer activity and overcomes tumor cell drug resistance. Nano Research 10, 652 (2017).

268. O.V. Lynchak, Y.I. Prylutskyy, V.K. Rybalchenko et al. Comparative analysis of the antineoplastic activity of $\mathrm{C}_{60}$ fullerene with 5 -fluorouracil and pyrrole derivative in vivo. Nanoscale Res. Lett. 12, 8 (2017).

269. M. Kubovcikova, I.V. Gapon, V. Zavisova et al. On the adsorption properties of magnetic fluids: Impact of bulk structure. J. Magn. Magn. Mater. 427, 67 (2017).

270. M. Rajnak, M. Timko, P. Kopcansky et al. Structure and viscosity of a transformer oil-based ferrofluid under an external electric field. J. Magn. Magn. Mater. 431, 99 (2017).

271. M. Molcan, V.I. Petrenko, M.V. Avdeev et al. Structure characterization of the magnetosome solutions for hyperthermia study. J. Mol. Liq. 235, 11 (2017).

272. N.A. Atamas, V. Bardik, A. Bannikova et al. The effect of water dynamics on conformation changes of albumin in pre-denaturation state: Photon correlation spectroscopy and simulation. J. Mol. Liq. 235, 17 (2017).

273. V. Chumachenko, N. Kutsevol, Yu. Harahuts et al. Starlike dextran-graft-pnipam copolymers. Effect of internal molecular structure on the phase transition. J. Mol. Liq. 235, 77 (2017).

274. V. Gdovinova, N. Tomasovicova, I. Batko et al. Interaction of magnetic nanoparticles with lysozyme amyloid fibrils. J. Magn. Magn. Mater. 431, 8 (2017).

275. D. Uhrikova, J. Teixeira, L. Hubcik et al. Lipid based drug delivery systems: Kinetics by SANS. J. Phys. Conf. Ser. 848, 012007 (2017).

276. L. Balejcikova, V.I. Petrenko, M.V. Avdeev et al. Small-angle scattering on magnetoferritin nanoparticles. J. Phys. Conf. Ser. 848, 012011 (2017).

277. Yu.E. Gorshkova, O.I. Ivankov. Structure and phase transitions of the multilamellar DMPC membranes in presence of the DMSO and DESO. J. Phys. Conf. Ser. 848, 012014 (2017).

278. R.Yu. Smyslov, K.V. Ezdakova, G.P. Kopitsa et al. Morphological structure of Gluconacetobacter xylinus cellu- lose and cellulose-based organic-inorganic composite materials. J. Phys. Conf. Ser. 848, 012017 (2017).

279. A.C. Dragolici, M. Balasoiu, O.L. Orelovich et al. CEM $\mathrm{V}$ based special cementitious materials investigated by means of SANS method. Preliminary results. J. Phys. Conf. Ser. 848, 012024 (2017).

280. A.-M. Balasoiu-Gaina, M. Balasoiu, O.I. Ivankov et al. Structural analysis of aqueous ferrofluids with cobalt ferrite particles stabilized with lauric acid and sodium n-dodecyl sulphate. J. Phys. Conf. Ser. 848, 012026 (2017).

281. E. Wozniak, M. Spirkova, M. Slouf et al. Stabilization of aqueous dispersions of poly(methacrylic acid)-coated iron oxide nanoparticles by double hydrophilic block polyelectrolyte poly(ethylene oxide)-block-poly(N-methyl-2vinylpyridinium iodide). Colloids Surf. A 514, 32 (2017).

282. A. Zou, Y. Li, Y. Chen et al. Self-assembled stable spongetype nanocarries for Brucea javanica oil delivery. Colloids Surf. B 153, 310 (2017).

283. L. Balejcikova, V.M. Garamus, M.V. Avdeev et al. The effect of solution $\mathrm{pH}$ on the structural stability of magnetoferritin. Colloids Surf. B 156, 375 (2017).

284. O. Holderer, M. Khaneft, Y. Lin et al. Nanostructure of HT-PEFC electrodes investigated with scattering methods. ECS Trans. 80, 19 (2017).

285. J. Blass, J. Brunke, F. Emmerich et al. Interactions between shape-persistent macromolecules as probed by AFM. Beilstein J. Org. Chem. 13, 938 (2017).

286. S. Drescher, V.M. Garamus, C. Garvey et al. Aggregation behaviour of a single-chain, phenylene-modified bolalipid and its miscibility with classical phospholipids. Beilstein J. Org. Chem. 13, 995 (2017).

287. S. Prylutska, S. Politenkova, K. Afanasieva et al. A nanocomplex of $\mathrm{C}_{60}$ fullerene with cisplatin: design, characterization and toxicity. Beilstein J. Nanotechnol. 8, 1494 (2017).

288. C. Mark, O. Holderer, J. Allgaier et al. Polymer chain conformation and dynamical confinement in a model onecomponent nanocomposite. Phys. Rev. Lett. 119, 047801 (2017).

289. N. Kampman, P. Bertier, A. Busch et al. Validating reactive transport models of $\mathrm{CO}_{2}$-brine-rock reactions in caprocks using observations from a natural $\mathrm{CO}_{2}$ reservoir. Energy Procedia 114, 4902 (2017).

290. D. Schwahn, V. Pipich, R. Kasher. Phase behavior of methacrylic acid, poly(ethylene glycol) methyl ether, and poly(ethylene glycol) methacrylate in aqueous solutions. Polymer 121, 111 (2017).

291. B.-J. Niebuur, K.-L. Claude, S. Pinzek et al. Pressuredependence of poly $(\mathrm{N}$-isopropylacrylamide) mesoglobule formation in aqueous solution. ACS Macro Lett. 6, 1180 (2017).

292. S.A. Lermontov, A.N. Malkova, N.A. Sipyagina et al. Comparative analysis of the physicochemical characteristics of $\mathrm{SiO}_{2}$ aerogels prepared by drying under subcritical and supercritical conditions. Inorg. Mater. 53, 1270 (2017).

ISSN 2071-0194. Ukr. J. Phys. 2020. Vol. 65, No. 8 
293. A. Raj, M. Wang, T. Zander et al. Lubrication synergy: Mixture of hyaluronan and dipalmitoylphosphatidylcholine (DPPC) vesicles. J. Colloid Interf. Sci. 488, 225 (2017).

294. J. Skvarla, R.K. Raya, M. Uchman et al. Thermoresponsive behavior of poly(N-isopropylacrylamide)s with dodecyl and carboxyl terminal groups in aqueous solution: $\mathrm{pH}-$ dependent cloud point temperature. Colloid Polym. Sci. 295, 1343 (2017).

295. A. Angelova, V.M. Garamus, B. Angelov et al. Advances in structural design of lipid-based nanoparticle carriers for delivery of macromolecular drugs, phytochemicals and anti-tumor agents. Adv. Colloid Interf. Sci. 249, 331 (2017).

296. S.R. Al-Ayoubi, P.H. Schummel, M. Golub et al. Influence of cosolvents, self-crowding, temperature and pressure on the sub-nanosecond dynamics and folding stability of lysozyme. Phys. Chem. Chem. Phys. 19, 14230 (2017).

297. M. Golub, S. Combet, D.C.F. Wieland et al. Solution structure and excitation energy transfer in phycobiliproteins of Acaryochloris marina investigated by small angle scattering. Biochim. Biophys. Acta 1858, 318 (2017).

298. M. Golub, B. Lehofer, N. Martinez et al. High hydrostatic pressure specifically affects molecular dynamics and shape of low-density lipoprotein particles. Sci. Rep. 7, 46034 (2017).

299. M. Golub, M. Hejazi, A. Koelsch et al. Solution structure of monomeric and trimeric photosystem I of Thermosynechococcus elongatus investigated by small-angle X-ray scattering. Photosynth. Res. 133, 163 (2017).

300. T. Kondela, J. Gallova, T. Hauss et al. Effect of alkan1-ols on the structure of dopc model membrane. Eur. Pharm. J. 64, 4 (2017)

301. R. Xiong, H.S. Kim, S. Zhang et al. Template-guided assembly of silk fibroin on cellulose nanofibers for robust nanostructures with ultrafast water transport. ACS Nano 11, 12008 (2017).

302. E.A. Lysenkov, V.V. Klepko, I.P. Lysenkova. Features of microstructure and percolation behavior of polypropylene glycol, filled by multiwalled carbon nanotubes. J. Nano Electron. Phys. 9, 05021 (2017).

303. E.A. Lysenkov, V.V. Klepko, I.P. Lysenkova. Influence of modification of carbon nanotubes on the microstructure and percolation behavior of the systems based on polyethylene glycol. J. Phys. Stud. 21, 4701 (2017).

304. E.A. Lysenkov, Z.O. Haholkina, E.V. Lobko et al. Influence of carbon nanotubes on the mechanical properties of cross-linked polyurethanes. Mater. Sci. 53, 14 (2017).

305. N. Lebovka, L. Bulavin, V. Kovalchuk et al. Two-step percolation in aggregating systems. Condens. Matter Phys. 20, 13602 (2017).

306. O.V. Tomchuk, M.V. Avdeev, L.A. Bulavin et al. Study of tetraethoxysilane clusters in basic ethanol/water solutions by SANS contrast variation. Roman. J. Phys. 63, 906 (2018).
307. L.A. Bulavin, T.V. Nagorna, O.A. Kyzyma et al. Fullerene clustering in $\mathrm{C}_{70} / \mathrm{N}$-methyl-2-pyrrolidone/toluene liquid system. Ukr. J. Phys. 63, 116 (2018).

308. A.V. Nagornyi, M.V. Avdeev, O.V. Yelenich et al. Structural aspects of $\mathrm{Fe}_{3} \mathrm{O}_{4} / \mathrm{CoFe}_{2} \mathrm{O}_{4}$ magnetic nanoparticles according to X-ray and neutron scattering. J. Surf. Invest. 12, 737 (2018)

309. T.V. Nagorna, M.O. Kuzmenko, O.A. Kyzyma et al. Structural reorganization of fullerene $\mathrm{C}_{70}$ in N-methyl2-pyrrolidone/toluene mixtures. J. Mol. Liq. 272, 948 (2018).

310. T.V. Nagorna, O.A. Kyzyma, L.A. Bulavin et al. Specifics of $\mathrm{C}_{60}$ fullerene cluster formation in a solvent mixture of toluene and N-methyl-2-pyrollidone. J. Surf. Invest. 18, 872 (2018).

311. L.A. Bulavin, Y. Prylutskyy, O. Kyzyma et al. Selforganization of pristine $\mathrm{C}_{60}$ fullerene and its complexes with chemotherapy drugs in aqueous solution as promising anticancer agents. In: Modern Problems of Molecular Physics. Selected Reviews from the 7th International Conference "Physics of Liquid Matter: Modern Problems", Kyiv, Ukraine, May 27-31, 2016, edited by L.A. Bulavin, A.V. Chalyi (Springer, 2018), p. 3.

312. A. Borowik, Y. Prylutskyy, L. Kawelski et al. Does $\mathrm{C}_{60}$ fullerene act as a transporter of small aromatic molecules? Colloids Surf. B 164, 134 (2018).

313. I.V. Byelinska, H.M. Kuznietsova, N.V. Dziubenko et al. Effect of $\mathrm{C}_{60}$ fullerenes on the intensity of colon damage and hematological signs of ulcerative colitis in rats. Mater. Sci. Eng. C 93, 505 (2018).

314. T. Halenova, N. Raksha, T. Vovk et al. Effect of $\mathrm{C}_{60}$ fullerene nanoparticles on the diet-induced obesity in rats. Int. J. Obes. 42, 1987 (2018).

315. V.I. Petrenko, O.P. Artykulnyi, L.A. Bulavin et al. On the impact of surfactant type on the structure of aqueous ferrofluids. Colloids Surf. A 541, 222 (2018).

316. X. Li, V.M. Garamus, N. Li et al. Preparation and characterization of a $\mathrm{pH}$-responsive mesoporous silica nanoparticle dual-modified with biopolymers. Colloids Surf. A 548, 61 (2018).

317. I.V. Gapon, V.I. Petrenko, O. Soltwedel et al. Crystalisation of aqueous ferrofluids at the free liquid interface investigated by specular and off-specular X-ray reflectometry. J. Phys. Conf. Ser. 994, 012008 (2018).

318. D. Creanga, M. Balasoiu, D. Soloviov et al. Small-angle neutron scattering investigations of Co-doped iron oxide nanoparticles. Preliminary results. J. Phys. Conf. Ser. 994, 012009 (2018).

319. D.V. Zabelskii, A.V. Vlasov, Yu.V. Ryzhykau et al. Ambiguities and completeness of SAS data analysis: investigations of apoferritin by SAXS/SANS EID and SEC-SAXS methods. J. Phys. Conf. Ser. 994, 012017 (2018).

320. A.N. Khodan, G.P. Kopitsa, K.E. Yorov et al. Structural analysis of aluminum oxyhydroxide aerogel by small angle X-ray scattering. J. Surf. Invest. 12, 296 (2018).

321. V.I. Petrenko, Y.N. Kosiachkin, L.A. Bulavin et al. On enhancement of the adsorption-layer effect at the metallic 
electrode-liquid electrolyte interface in specular neutron reflectometry experiments. J. Surf. Invest. 12, 651 (2018).

322. O.P. Artykulnyi, V.I. Petrenko, L.A. Bulavin et al. On the impact of polyethylene glycol on the structure of aqueous micellar solutions of sodium oleate according to smallangle neutron scattering. J. Surf. Invest. 12, 1142 (2018).

323. S.V. Snegir, O.P. Artykulnyi, V.I. Petrenko et al. On the in-depth density distribution of layered assemblies of $\mathrm{Au}$ nanoparticles on planar interfaces. Chem. Phys. Lett. 706, 601 (2018)

324. H. Yalcinkaya, A. Feoktystov, M. Gradzielski. Formation of well-defined vesicles by styrene addition to a nonionic surfactant and their polymerization leading to viscous hybrid systems. Langmuir 34, 9184 (2018).

325. A. Busch, N. Kampman, P. Bertier et al. Predicting effective diffusion coefficients in mudrocks using a fractal model and small-angle neutron scattering measurements. Water Resour. Res. 54, 7076 (2018).

326. J. Siefker, R. Biehl, M. Kruteva et al. Confinement facilitated protein stabilization as investigated by smallangle neutron scattering. J. Am. Chem. Soc. 140, 12720 (2018).

327. V. Ryukhtin, S. Bakai, T.-G. Shin et al. Microstructural investigations of bulk metallic glass using small-angle neutron scattering techniques. Physica B 551, 29 (2018).

328. J. Bahadur, L.F. Ruppert, V. Pipich et al. Porosity of the Marcellus Shale: A contrast matching small-angle neutron scattering study. Int. J. Coal Geol. 188, 156 (2018).

329. L.M. Anovitz, J.T. Freiburg, M. Wasbrough et al. The effects of burial diagenesis on multiscale porosity in the St. Peter Sandstone: An imaging, small-angle, and ultrasmall-angle neutron scattering analysis. Mar. Pet. Geol. 92, 352 (2018)

330. B. Wu, M. Siglreitmeier, C. Debus et al. Ionic dependence of gelatin hydrogel architecture explored using small and very small angle neutron scattering technique. Macromol. Biosci. 18, 1800018 (2018).

331. A.N. Bugrov, A.Yu. Zavialova, R.Yu. Smyslov et al. Luminescence of $\mathrm{Eu}^{3+}$ ions in hybrid polymer-inorganic composites based on poly(methyl methacrylate) and zirconia nanoparticles. Luminescence 33, 837 (2018).

332. C. Vasilescu, M. Latikka, K.D. Knudsen et al. High concentration aqueous magnetic fluids: structure, colloidal stability, magnetic and flow properties. Soft Matter 14, 6648 (2018).

333. O.L. Paiuk, N.Ye. Mitina, A.O. Riabtseva et al. Structure and colloidal-chemical characteristics of polymeric surface active substances based on polyethylene glycol-containing macromeres. Vopr. Khim. Khim. Tekhnol. 6, 63 (2018) (in Ukrainian).

334. Y. Yang, J. Cheng, V.M. Garamus et al. Preparation of an environmentally friendly formulation of the insecticide nicotine hydrochloride through encapsulation in chitosan/tripolyphosphate nanoparticles. J. Agric. Food Chem. 66, 1067 (2018).

335. A. Zou, Y. Yang, J. Cheng et al. Construction and characterization of a novel sustained-release delivery system for hydrophobic pesticides using biodegradable polydopamine-based microcapsules. J. Agric. Food Chem. 66, 6262 (2018).

336. S. Drescher, C. Otto, S. Mueller et al. Impact of headgroup asymmetry and protonation state on the aggregation behavior of a new type of glycerol diether bolalipid. Langmuir 34, 4360 (2018).

337. M. Nedielko, O. Alekseev, V. Chornii et al. Structure and properties of microcrystalline cellulose "ceramicslike" composites incorporated with $\mathrm{LaVO}_{4}$ :Sm oxide compound. Acta Phys. Pol. A 133, 838 (2018).

338. K. Recko, U. Klekotka, B. Kalska-Szostko et al. Properties of Ga-doped magnetite nanoparticles. Acta Phys. Pol. A 134, 998 (2018).

339. K. Recko, J. Waliszewski, U. Klekotka et al. Phase composition and magnetism of sol-gel synthesized $\mathrm{Ga}-\mathrm{Fe}-\mathrm{O}$ nanograins. Phase Transit. 91, 128 (2018).

340. V.A. Vizgalov, T. Nestler, L.A. Trusov et al. Enhancing lithium-ion conductivity in NASICON glass-ceramics by adding yttria. Cryst. Eng. Comm. 20, 1375 (2018).

341. E.V. Zemlyanaya, M.A. Kiselev, E.I. Zhabitskaya et al. The small-angle neutron scattering data analysis of the phospholipid transport nanosystem structure. J. Phys. Conf. Ser. 1023, 012017 (2018).

342. V.F. Korolovych, V. Cherpak, D. Nepal et al. Cellulose nanocrystals with different morphologies and chiral properties. Polymer 145, 334 (2018).

343. R. Xiong, H.S. Kim, L. Zhang et al. Wrapping nanocellulose nets around graphene oxide sheets. Angew. Chem. 57, 8508 (2018).

344. A.J. Erwin, V.F. Korolovych, Z. Iatridi et al. Tunable compartmentalized morphologies of multilayered dual responsive star block polyampholytes. Macromolecules 51, 4800 (2018).

345. V.F. Korolovych, A.J. Erwin, A. Stryutsky et al. Thermally responsive hyperbranched poly(ionic liquid)s: Assembly and phase transformations. Macromolecules 51, 4923 (2018).

346. V. Cherpak, V.F. Korolovych, R. Geryak et al. Robust chiral organization of cellulose nanocrystals in capillary confinement. Nano Lett. 18, 6770 (2018).

347. A.J. Erwin, H. Lee, S. Ge et al. Viscoelastic properties and ion dynamics in star-shaped polymerized ionic liquids. Eur. Polym. J. 109, 326 (2018).

348. N.A. Ogurtsov, Yu.V. Noskov, O.S. Kruglyak et al. Effect of the Dopant Anion and Oxidant on the Structure and Properties of Nanocomposites of Polypyrrole and Carbon Nanotubes. Theor. Exp. Chem. 54, 114 (2018).

349. M.L. Karpets, T.V. Tropin, L.A. Bulavin et al. Neutron reflectometry for structural studies in thin films of polymer nanocomposites. Modeling. Yad. Fiz. Energet. 19, 376 (2018) (in Ukrainian).

350. G. Graf, S. Drescher, A. Meister et al. Nanofiber formation and polymerization of bolalipids with diacetylenemodified single alkyl chains. J. Phys. Chem. B 123, 1566 (2019).

ISSN 2071-0194. Ukr. J. Phys. 2020. Vol. 65, No. 8 
351. O.V. Tomchuk, M.V. Avdeev, A.E. Aleksenskii et al. Sol-gel transition in nanodiamond aqueous dispersions by small-angle scattering. J. Phys. Chem. C 123, 18028 (2019).

352. A.N. Alekseev, S.A. Alekseev, Y.F. Zabashta et al. Twodimensional ordered crystal structure formed by chain molecules in the pores of solid matrix. In: Nanocomposites, Nanostructures, and Their Applications. Selected Proceedings of the 6th International Conference Nanotechnology and Nanomaterials (NANO2018), August 27-30, 2018, Kyiv, edited by O. Fesenko, L. Yatsenko (Springer, 2019), p. 387.

353. A.V. Stryutsky, V.F. Korolovych, H. Lee et al. Oligomeric and polymeric ionic liquids: Engineering architecture and morphology. In: Modern Problems of the Physics of Liquid Systems. Selected Reviews from the 8th International Conference "Physics of Liquid Matter: Modern Problems", Kyiv, Ukraine, May 18-22, 2018, edited by L.A. Bulavin, Limei Xu (Springer, 2019), p. 93.

354. N. Lebovka, L. Lisetski, L.A. Bulavin. Organization of nano-disks of Laponite in soft colloidal systems. In: Modern Problems of the Physics of Liquid Systems. Selected Reviews from the 8th International Conference "Physics of Liquid Matter: Modern Problems", Kyiv, Ukraine, May 18-22, 2018, edited by L.A. Bulavin, Limei Xu (Springer, 2019), p. 137.

355. O.V. Tomchuk. Some aspects of small-angle scattering by fractal chains. AIP Conf. Proc. 2163, 020006 (2019).

356. M.V. Avdeev, M.S. Yerdauletov, O.I. Ivankov et al. On the effect of carbon additives on the porosity of positive electrodes based on $\mathrm{LiFePO}_{4}$ for lithium-ion batteries. $J$. Surf. Invest. 13, 614 (2019).

357. L.A. Azarova, G.P. Kopitsa, E.G. Iashina et al. Model of fractal particles of hydrated zirconium dioxide, based on small-angle neutron scattering data. J. Surf. Invest. 13, 908 (2019)

358. O.V. Tomchuk, M.V. Avdeev, O.I. Ivankov et al. Features of colloidal aggregation in tetraethoxysilane-waterethanol ternary mixtures by small-angle neutron scattering. J. Surf. Invest. 13, 1122 (2019).

359. A. Nagornyi, V.I. Petrenko, M. Rajnak et al. Particle assembling induced by non-homogeneous magnetic field at transformer oil-based ferrofluid/silicon crystal interface by neutron reflectometry. Appl. Surf. Sci. 473, 912 (2019).

360. O. Kyzyma, N. Bashmakova, Y. Gorshkova et al. Interaction between the plant alkaloid berberine and fullerene $\mathrm{C}_{70}$ : Experimental and quantum-chemical study. J. Mol. Liq. 278, 452 (2019).

361. S.V. Snegir, T.V. Tropin, O.A. Kyzyma et al. On a specific state of $\mathrm{C}_{60}$ fullerene in N-methyl-2-pyrrolidone solution: Mass spectrometric study. Appl. Surf. Sci. 481, 1566 (2019)

362. O.A. Kyzyma, M.V. Avdeev, O.I. Bolshakova et al. State of aggregation and toxicity of aqueous fullerene solutions. Appl. Surf. Sci. 483, 69 (2019).
363. V.A. Vizgalov, T. Nestler, A. Vyalikh et al. The role of glass crystallization processes in preparation of high Liconductive NASICON-type ceramics. Crys. Eng. Comm. 21, 3106 (2019)

364. P.P. Gorbyk, I.V. Pylypchuk, V.I. Petrenko et al. Synthesis and characterization of hybrid chitosan/magnetite nanocomposite fluid. J. Nano Electron. Phys. 11, 04017 (2019).

365. O.P. Artykulnyi, V.I. Petrenko, L.A. Bulavin et al. Impact of poly (ethylene glycol) on the structure and interaction parameters of aqueous micellar solutions of anionic surfactants. J. Mol. Liq. 276, 806 (2019).

366. L.A. Bulavin, N.A. Goncharenko, O.P. Dmytrenko et al. Heteroassociation of antitumor agent doxorubicin with bovine serum albumin in the presence of gold nanoparticles. J. Mol. Liq. 284, 633 (2019).

367. L. Balejcikova, V.I. Petrenko, M. Batkova et al. Disruption of amyloid aggregates by artificial ferritins. J. Magn. Magn. Mater. 473, 215 (2019).

368. L. Balejcikova, J. Kovac, V.M. Garamus et al. Influence of synthesis temperature on structural and magnetic properties of magnetoferritin. Mendeleev Commun. 29, 279 (2019).

369. V.Y. Kutsenko, O.P. Artykulnyi, V.I. Petrenko et al. Isotope effect in heavy/light water suspensions of optically active gold nanoparticles. Appl. Nanosci. 9, 957 (2019).

370. J. Witte, T. Kyrey, J. Lutzki et al. A comparison of the network structure and inner dynamics of homogeneously and heterogeneously crosslinked PNIPAM microgels with high crosslinker content. Soft Matter 15, 1053 (2019).

371. T. Kyrey, J. Witte, A. Feoktystov et al. Inner structure and dynamics of microgels with low and medium crosslinker content prepared via surfactant-free precipitation polymerization and continuous monomer feeding approach. Soft Matter 15, 6536 (2019).

372. T. Zander, D.C.F. Wieland, A. Raj et al. Influence of high hydrostatic pressure on solid supported DPPC bilayers with hyaluronan in the presence of $\mathrm{Ca}^{2+}$ ions. Soft Matter 15, 7295 (2019).

373. T. Kyrey, J. Witte, M. Pipich et al. Influence of the crosslinker content on adsorbed functionalised microgel coatings. Polymer 169, 29 (2019).

374. M. Gvaramia, G. Mangiapia, V. Pipich et al. Tunable viscosity modification with diluted particles: when particles decrease the viscosity of complex fluids. Colloid Polym. Sci. 297, 1507 (2019).

375. E.P. Simonenko, N.P. Simonenko, G.P. Kopitsa et al. A sol-gel synthesis and gas-sensing properties of finely dispersed $\mathrm{ZrTiO}_{4}$. Mater. Chem. Phys. 225, 347 (2019).

376. V. Pipich, K. Schlenstedt, M. Dickmann et al. Morphology and porous structure of standalone aromatic polyamide films as used in RO membranes - An exploration with SANS, PALS, and SEM. J. Membr. Sci. 573, 167, (2019).

377. S.P. Schwaminger, S.A. Blank-Shim, I. Scheifele et al. Design of interactions between nanomaterials and proteins: 
A highly affine peptide tag to bare iron oxide nanoparticles for magnetic protein separation. Biotechnol. J. 14, 1800055 (2019).

378. I. Titov, M. Barbieri, P. Bender et al. Effect of grainboundary diffusion process on the geometry of the grain microstructure of Nd-Fe-B nanocrystalline magnets. Phys. Rev. Mater. 3, 084410 (2019).

379. Kh.E. Yorov, S.Yu. Kottsov, A.E. Baranchikov et al. Photoluminescent porous aerogel monoliths containing $\mathrm{ZnEu}-$ complex: the first example of aerogel modified with a heteronuclear metal complex. J. Sol-Gel Sci. Technol. 92, 304 (2019)

380. D.V. Lebedev, Ya.A. Zabrodskaya, V. Pipich et al. Effect of alpha-lactalbumin and lactoferrin oleic acid complexes on chromatin structural organization. Biochem. Biophys. Res. Commun. 520, 136 (2019).

381. C. Gonzalez-Chomon, V.M. Garamus, S. Rangelov et al. Trimethoxysilyl end-capped hyperbranched polyglycidol/polycaprolactone copolymers for cell delivery and tissue repair: synthesis, characterisation and aqueous solution properties. Eur. Polym. J. 112, 648 (2019).

382. T.R. Heyn, V.M. Garamus, H.R. Neumann et al. Influence of the polydispersity of $\mathrm{pH} 2$ and $\mathrm{pH} 3.5$ betalactoglobulin amyloid fibril solutions on analytical methods. Eur. Polym. J. 120, 109211 (2019).

383. N. Kalanda, V.M. Garamus, M.V. Avdeev et al. Smallangle neutron scattering and magnetically heterogeneous state in $\mathrm{Sr}_{2} \mathrm{FeMoO}_{6-\delta}$. Phys. Status Solidi $B \mathbf{2 5 6}$, 1800428 (2019).

384. A. Angelova, M. Drechsler, V.M. Garamus et al. Pep-lipid cubosomes and vesicles compartmentalized by micelles from self-assembly of multiple neuroprotective building blocks including a large peptide hormone PACAP-DHA. ChemNanoMat 5, 1381 (2019).

385. M. Knaapila, B. Stewart, V.M. Garamus et al. Poly(9undecyl-9-methyl-fluorene) and poly(9-pentadecyl-9-methyl-fluorene): Synthesis, solution structure, and effect of side chain asymmetry on aggregation behavior. J. Polym. Sci. B 57, 826 (2019).

386. C. Debus, B. Wu, T. Kollmann et al. Bioinspired multifunctional layered magnetic hybrid materials. Bioinspir. Biomim. Nan. 8, 28 (2019).

387. V. Chumachenko, N. Kutsevol, Iu. Harahuts et al. Temperature driven transformation in dextran-graftPNIPAM/embedded silver nanoparticle hybrid system. Int. J. Polym. Sci. 2019, 3765614 (2019).
388. A. Zelenakova, P. Hrubovcak, O. Kapusta et al. Size and distribution of the iron oxide nanoparticles in SBA-15 nanoporous silica via SANS study. Sci. Rep. 9, 15852 (2019).

389. T.B. Feldman, O.I. Ivankov, A.I. Kuklin et al. Small-angle neutron and X-ray scattering analysis of the supramolecular organization of rhodopsin in photoreceptor membrane. Biochim. Biophys. Acta 1861, 183000 (2019).

390. S. Kim, V.F. Korolovych, M.J. Weissburg et al. Morphology and surface properties of roach water transport arrays. ACS Appl. Bio. Mater. 2, 2650 (2019).

391. H. Lee, A.V. Stryutsky, V.F. Korolovych et al. Transformations of thermosensitive hyperbranched poly(ionic liquid)s monolayers. Langmuir 35, 11809 (2019).

392. L.A. Bulavin, Yu.F. Zabashta, L.Yu. Vergun et al. Interfacial layers and the shear elasticity of the collagen-water system. Ukr. J. Phys. 64, 34 (2019).

393. O.M. Alekseev, S.O. Alekseev, Yu.F. Zabashta et al. Influence of open-porous system on the solid-state phase transition in 1-octadecene. Ukr. J. Phys. 64, 340 (2019).

394. N. Lebovka, Yu.Yu. Tarasevich, L.A. Bulavin et al. Sedimentation of a suspension of rods: Monte Carlo simulation of a continuous two-dimensional problem. Phys. Rev. E 99, 052135 (2019).

Received 13.03.20.

Translated from Ukrainian by O.I. Voitenko

O.В. Томчук

\section{ФРАКТАЛЬНА КОНЦЕПЦЯ}

В СТРУКТУРНОМУ АНАЛІЗІ НАНОСИСТЕМ: РЕТРОСПЕКТИВНИЙ ПОГЛЯД І ПЕРСПЕКТИВИ

$\mathrm{P}$ е $з$ ю м е

Концепція фракталів широко використовується в різноманітних галузях науки. На прикладі результатів наукової школи Л.А. Булавіна була продемонстрована тенденція до все активнішого застосування фрактального аналізу в структурних дослідженнях наносистем. В роботі показано, що особливості розподілів наносистем за фрактальними розмірностями пов'язані з механізмами росту і агрегації дисперсної фази. Важливим аспектом є саме кінетика процесу під дією різних чинників. Підкреслена провідна роль методів малокутового розсіяння (аналіз в оберненому просторі Фур'є) в поєднанні з методами мікроскопї (аналіз в прямому просторі) при дослідженні актуальних наноструктурованих матеріалів в різних агрегатних станах. 